\title{
ESTUDIOS
}

\section{LA VIDA Y LA BIBLIOTECA DE BERNABÉ GARCÍA, BOTICARIO RURAL DEL SIGLO XVIII}

\author{
Félix Martín Verdejo
}

IES Pradolongo, Madrid

\section{RESUMEN}

Bernabé García (1673-1752), boticario, agricultor, arrendador de diezmos, etc., fue un hombre que, aún viviendo en la sociedad rural, no dio la espalda a las novedades culturales de su tiempo. Su modesta pero interesante biblioteca, de unos cien volúmenes, es quien mejor lo radiografía. Era una persona profundamente religiosa, con pretensiones nobles, forma de vida burguesa, inquietudes preilustradas y cualidades de proyectista.

PALABRAS CLAVE: Historia de la farmacia, Historia sociocultural, Historia rural, siglo XVIII, Castilla La Mancha.

\section{SUMMARY}

Bernabé García (1673-1752), was an apothecary, a farmer, a tax collector for Catholic Church, who lived in a rural society, but he was interested in cultural newness of his time. His modest but interesting library (about a hundred books) shows his personality. He was a profoundly religious person, a middle-class man worried to become nobleman, with preenlightened ideas and utopian's qualities.

KEY WORDS: History of pharmacy, social and cultural history, rural history, $18^{\text {th }}$ Century, Castilla La Mancha.

\section{INTRODUCCIÓN}

Bernabé García Bermúdez Cabeza de Vaca (1673-1752), nace y muere en Domingo Pérez, Toledo. Fue boticario hasta que en 1710 abandona su profesión para dedicarse a la agricultura, a arrendar diezmos y a otras ocupaciones. Desarrolló su vida en la sociedad rural pero no fue un campesino al uso. Su 
padre, cirujano latino, le transmitió la curiosidad intelectual y los deseos por la cultura. De la familia de la madre, hidalgos empobrecidos, recibió lo más conservador de su mentalidad, así como la obsesión por las genealogías. Todo ello se refleja en su más que estimable biblioteca.

Bernabé García fue un hombre de su tiempo, y participó en él más de lo que cabía esperar. Visto desde nuestros días, es una figura atractiva que nos sorprende por su rica personalidad. Dejó la farmacia porque le condenaba a una existencia estrecha, de limitados horizontes, y él pretendía alcanzar esferas sociales y políticas más altas. En su vida se encierra mucho de la historia de España de aquellos años. En el plano cultural encontramos las nuevas ideas que tratan de introducir los preilustrados o novadores. En lo político, la Guerra de Sucesión, las iniciativas regalistas, la preocupación por el ejército. En lo económico, el aumento de tributos, la ruina progresiva del campo, los censos. Y en lo social, la contestación cada vez mayor del pueblo llano hacia el estamento eclesiástico, por la evasión de impuestos, por sus privilegios en general, por las capellanías.

Con Bernabé García, la gestión del ayuntamiento gana en orden, rigor y racionalidad. Se toman medidas acordes con los tiempos que corren: aseo de calles, arreglos de caminos, vigilancia de la higiene de tiendas y de carnicería, mejoras en el abastecimiento de agua potable, construcción de fuentes públicas, etc. Podríamos decir que aplica a la villa el reformismo y la modernización que los borbones llevan a cabo en España.

El trabajo que presentamos comienza con la vida de Bernabé García, la parte más extensa. Es una existencia larga, de casi 80 años, muy documentada, que hemos dividido en cinco etapas:

1. Desde su nacimiento a su regreso a Domingo Pérez, ya casado, donde abre la botica (1673-1696).

2. Hasta la venta de la botica en 1710 .

3. La siguiente etapa finaliza con la información de 1726 .

4. Hasta la cesión de bienes a su hija y yerno en 1743.

5. Últimos años de su vida.

El segundo punto del trabajo examina su biblioteca, hecha a su imagen y semejanza, de la que se sentía muy orgulloso. Gracias a ella se instruyó, se formó intelectualmente, se hizo mejor ciudadano y una persona más libre. Es una biblioteca barroca, de casi cien volúmenes, en la que prima la materia religiosa y la historia, pero en la que caben también las obras de ciencia y los textos preilustrados. A través de ella descubrimos a un Bernabé García tradicional, 
arraigado en el pasado, pero en absoluto cerrado al futuro y a las novedades del presente. La biblioteca se la dejará en herencia a su nieto con la intención, nos dice, de que «sea un hombre», un hombre preparado, independiente.

En la Conclusión, punto siguiente, insistimos en los aspectos que nos han parecido más relevantes de todo lo anterior, con el propósito de perfilar y definir mejor la figura de Bernabé García.

El Apéndice reproduce la biblioteca de Bernabé García tal como aparece en la escritura de 1743. Las notas correspondientes a las obras procuran identificarlas, proporcionan las ediciones más adecuadas y destacan la importancia cultural de aquellas que lo merecen. El Apéndice también contiene los libros que Bernabé García hereda de su padre.

No es fácil encontrar hombres como Bernabé García en el ámbito rural. Quizá fueron más comunes en poblaciones mayores y sobre todo a partir de la segunda mitad del siglo XVIII, cuando la Ilustración triunfa y se multiplican las Instituciones culturales, las Sociedades Económicas de Amigos del País, los periódicos, etc. Resulta complicado enjuiciar su labor cultural por falta de datos. Desconocemos si su biblioteca fue celosamente cerrada al público o su generosidad permitió que accedieran a ella aquellos que sabían leer y tenían interés por aprender. Sabemos que prestaba libros a su sobrino, por lo que podemos imaginar que lo hiciera también con otras personas. De igual forma podemos pensar que se reuniera en tertulias con el médico, algún clérigo y otras personas de la villa o de la comarca. Estamos seguros de que Bernabé García gustaba de la conversación y de la polémica. Menos incierta resulta su aportación al gobierno municipal y su mecenazgo artístico en la iglesia. En cuanto a lo primero, ya se ha ido señalando su aportación en distintos lugares del trabajo. Con respecto a lo segundo, todavía hoy podemos contemplar el retablo mayor de la iglesia, con las imágenes que lo adornan, que él financió; y la capilla de San Antonio de Padua de la que fue su principal impulsor, y en la que también contribuyó con su dinero y sus propiedades. En un mundo tan cerrado y tan atrasado como entonces era el rural, personas como Bernabé García deben ser reconocidas y recordadas, por lo que suponen de apertura y progreso.

\section{VIDA DE BERNABÉ GARCÍA.}

Bernabé García Bermúdez Cabeza de Vaca nació en Domingo Pérez (Toledo) el 24 de abril de 1673 ${ }^{1}$. Sus padres fueron Eusebio García, cirujano de

\footnotetext{
1 Archivo Parroquial de Domingo Pérez (APDP), Libro de Bautismos.
} 
la villa ${ }^{2}$, y doña Josefa Bermúdez, naturales de Toledo 3 . Queda huérfano de madre en 1679, cuando aún no ha cumplido los seis años. El padre, que sepamos, no se volvió a casar, hecho muy habitual entonces. Dos meses antes de cumplir los quince años, muere el padre. Un tutor se ocupó, durante su minoría de edad, de solucionar los asuntos pendientes del padre y de velar por los bienes muebles, ningún bien raíz, que dejó a sus hijos ${ }^{4}$. No sabemos dónde estuvo y con quién desde la muerte del padre en 1688. Quizá vivió con los

2 Eusebio García fue cirujano de Domingo Pérez desde 1665 hasta el año de su muerte en 1688. Debía de ser cirujano latino a juzgar por el salario que percibía $(2.700,3.000$ reales anuales) y los libros en latín que poseía y después heredó su hijo (véase el Apéndice). Durante los años en que ejerció la cirugía en la villa, tampoco encontramos contratos con médicos, por lo que él debió de desempeñar las dos funciones. El primer salario del médico que conocemos por estos años son los 3.000 reales anuales de 1694 (Archivo Municipal de Domingo Pérez (AMDP), Libro de acuerdos).

En 1664, el cirujano que precedió a Eusebio García llega al siguiente acuerdo con la villa: curará todos los «carbuncos y apostemas y demás enfermedades de naciencias, como no sea heridas con parte»; «ha de tener piedra para que los labradores puedan acudir a amolar podaderas, hachas y otras herramientas»; "se le ha de dar cabalgadura para que traiga piedra de amolar a donde se hallare»; no faltará más de dos días de la villa, y si así no fuere la justicia pondrá una persona apropiada a su costa para que visite y cure a los enfermos; se le dará casa gratuita y estará libre de padrones y derramas; recibirá 1.800 reales por un año de trabajo (AMDP, Libro de acuerdos). Disponemos de dos contratos de Eusebio García, pero sin los detalles del anterior. Uno es del 25 de julio de 1669, por un año, 2.700 reales y casa gratuita. El otro es del 13 de julio de 1671, por tres años, 3.000 reales anuales y casa también gratuita; en éste se dice que es cirujano de la villa desde 1665 (AMDP, Libro de acuerdos). El cirujano de 1697 solicita al concejo un aumento de salario, porque con los 1.750 reales del actual no puede sustentarse, al tener que «pagar dos soldadas a dos mozos que le asisten para sangrar y quitar barbas». Se le conceden 550 reales más (AMDP, Libro de acuerdos). Veamos, finalmente, las obligaciones del cirujano en un contrato de 1678 , hecho en un pueblo de la zona, y por el que cobrará 600 reales: «quitar barbas, [hacer] sangrías, ventosas, postemas, carbuncos y nacencias, de cualquier manera que sean» (Archivo Histórico Provincial de Toledo (AHPT), protocolo 5.783). Véase LÓPEZ, M ${ }^{\mathrm{a}}$ L. y SALAVERT, V.L. (1999), «El barbero-cirujano», La aventura de la Historia, 5, 80-84. LÓPEZ, Ma L. (2002), «Médicos, cirujanos, boticarios y albéitares», Historia de la ciencia y de la técnica en la Corona de Castilla. III. Siglos XVI y XVII, Salamanca, Junta de Castilla y León, 161-185. MARTíNEZ, J. (2002), «La anatomía y los colegios de cirugía», Historia de la ciencia y de la técnica en la Corona de Castilla. IV. Siglo XVIII, Salamanca, Junta de Castilla y León, 269-294.

3 Los padres de Bernabé García se casan en 1665 (APDP). Los abuelos paternos son Bernabé García y doña Inés Suárez, y los maternos don Cristóbal Bermúdez y doña María de Rojas y Hoyos (los apellidos de esta última no están claros), naturales de Toledo.

4 Bernabé García anduvo en pleitos con su tutor, y en 1705 llegaron a un acuerdo (AHPT, protocolo 5.881). 
abuelos o los tíos en Toledo o con otros familiares en algún lugar de la provincia. En Domingo Pérez no tenía ningún pariente, hasta el padrino que lo tuvo en la pila bautismal había muerto en 1684. Pero en 1696 ya lo vemos, casado y de boticario, avecindado en la mencionada villa.

Bernabé García no cursó, pensamos, estudios universitarios, y si los hizo no obtuvo ningún grado porque nunca los alegó 5 . Además de las primeras letras, recibiría estudios de gramática, como conocemos de testimonios de otros boticarios de su tiempo ${ }^{6}$. F. Javier Puerto Sarmiento asegura que durante el Barroco para «ser recibidos a examen, los boticarios debían presentar fe de bautismo, información de limpieza de sangre y certificado de haber trabajado cuatro años con un maestro aprobado, quien debía emitir un informe sobre su capacidad» ${ }^{7}$. El periodo de aprendizaje de 4 años junto a un maestro boticario lo pudo realizar con su suegro o con su cuñado ${ }^{8}$. Tampoco creemos que supiera latín con el nivel y la profundidad de su padre, porque en su biblioteca aparecen pocos libros en esa lengua. Además, el uso del latín por los boticarios durante el siglo XVII no fue tan exigente como en el siglo XVI; a medida que pasan los años la obligatoriedad del latín es menor, y poco a poco se va imponiendo el romance ${ }^{9}$. Sus conocimientos y cultura los adquiriría principalmente de las abundantes y variadas lecturas, de los frecuentes viajes a Ma-

5 Revisamos libros de matricula de la Universidad de Toledo en el AHPT, pero no encontramos nada sobre Bernabé García. Hay poca documentación conservada y casi toda ella fuera de los límites cronológicos que nos interesan (AHPT, I-356, I-353, I-448, ...).

6 De 1746 es la escritura por la que el tutor de un futuro boticario de Domingo Pérez dice que le «ha alimentado, vestido y dado estudios hasta perfeccionarle en gramática» (AHPT, protocolo 5.887).

7 Puerto, F.J. (1997), El mito de Panacea. Compendio de Historia de la Terapéutica y de la Farmacia, Madrid, Doce Calles, p. 359.

8 No hemos podido confirmar que el suegro fuera boticario, pero el cuñado sí lo debía de ser porque en 1723 otorga poder a Bernabé García para que cobre al duque de Uceda 5.040 reales del importe de medicinas y recetas de botica que el otorgante le ha ido entregando desde 1708 a 1712 (AHPT, protocolo 5.883). Además, era muy usual que los hijos continuaran las profesiones de los padres, por lo que probablemente el suegro también fuera boticario.

9 Un acuerdo tomado por el Real Tribunal del Protomedicato en 1693 notifica a médicos y cirujanos latinos de Madrid que escriban las recetas de los «medicamentos compuestos o simples, con sus nombres naturales o comunes, de forma que todos los pudiesen entender» (MUÑOZ, S. (1994), Historia de la farmacia en la España moderna y contemporánea, Madrid, Síntesis, pp. 171 y 172). Según el testimonio del padre Isla, los boticarios y los sacristanes tenían fama de conocer deficientemente el latín: «Esto, porque hubo tal cual autor nuestro [de España] que realmente escribió en un latín charro ['aldeano'] y guedejudo ['enrevesado'], o como latín de boticario y sacristán.» (J.F. Isla, Fray Gerundio de Campazas, I, Espasa-Calpe, 1969, p. 161). 
drid y Toledo y de las distintas y diversas gentes con las que trataba y se relacionaba. Obligado por sus propios negocios, pero también movido por los poderes que le otorgaba la villa para solucionar diferentes asuntos, Bernabé García se desplazaba a esas ciudades, y en ellas permanecía varios días, tratando con consejeros, abogados, procuradores, visitadores eclesiásticos, nobles, jueces, escribanos, corregidores, intendentes, etc. Como era un hombre inteligente, despierto e interesado por las novedades del momento, sacaría provecho de esos habituales viajes y, a veces, estancias prolongadas de hasta 15 días ${ }^{10}$.

A principios de 1696, Bernabé García y su mujer, doña Francisca de Rojas y Balmaseda, se debieron trasladar a vivir a Domingo Pérez, donde establecieron la botica. La profesión farmacéutica en España por estos años y los primeros del siglo XVIII, según F. Javier Puerto, se caracteriza por su descentralización, falta de uniformidad e ineficacia institucional. Los Borbones tratarán de corregir todo esto, pero la enseñanza de la farmacia no cambiará sustancialmente hasta la segunda mitad del siglo XVIII, y continuará en poder de los gremios ${ }^{11}$. Doña Francisca era natural y vecina de La Puebla de Montalbán, y allí se desposaron «por palabras de presente» el 29 de septiembre de 1694, según certifica el párroco de Domingo Pérez cuando los vela el 23 de febrero de $1696^{12}$. El capital que lleva Bernabé García al matrimonio es de 5.766 reales, en lo que se aprecia los bienes muebles y las deudas de diferentes vecinos con el padre ${ }^{13}$; no tenemos noticias de la dote

10 Toledo menos, pero Madrid se convirtió en el mayor foco cultural de España.

11 Puerto (1997), 362-363 y 463 y ss. También, Puerto, F.J. (2002), «Empirismo, arte y creencia, en la época de la razón: la terapéutica farmacológica ilustrada», Historia de la ciencia y de la técnica en la Corona de Castilla. IV. Siglo XVIII, 239-267. Por su parte, Sagrario Muñoz Calvo afirma que la primera mitad del siglo XVIII «es una de las épocas más anárquicas e irregulares de los estudios y titulaciones de Farmacia» (MUÑOZ (1994), p. 210).

12 APDP, Libro de matrimonios.

13 La mitad de los 5.766 reales son de doña María García, su hermana monja, que se los dona. De ellos, casi 3.000 reales son deudas que le dejaron a deber al padre por su oficio de cirujano. Más de 500 reales son de libros. Los instrumentos de cirugía que quedaron del padre y que recoge la escritura son los siguientes: una sierra de cirugía ( 24 reales), tres hierros palmares (12 r.), tres botonales (6 r.), un espetoncillo ( $2 \mathrm{r}$.), unas tenacillas para sacar sedales (4 r.), unas tenacillas para sacar sanguijuelas $(6 \mathrm{r}$.), un fontanero $(15 \mathrm{r}$.) unas tenazas para quitar sanguijuelas ( $8 \mathrm{r}$.), un hierro para labrar la ciática (12 r.), un trépano con su mano (15 r.), cuatro cauterios ( 20 r.) un badal ( 6 r.), un hierro de cirugía que se llama 'especulum matricis' $(50 \mathrm{r}$.), tres legras $(15 \mathrm{r}$.), un verduguillo postemero, cuatro lancetas y unas tijeras, todo muy usado (20 r.). El capital de Bernabé García no registra ningún bien raíz: ni tierras de labor, ni viñas, ni olivos, ni casas; tampoco, ganados mayores ni menores (AHPT, protocolo 5.880). 
de su mujer ${ }^{14}$. El 12 de diciembre de 1696, por motivo de una real cédula que trataba de restablecer las milicias del diezmo de vecindades de Felipe II, se registran todas las casas de la villa de Domingo Pérez. Aparece en la lista Bernabé García, boticario, que «no quiso declarar cosa alguna por decir que tenía privilegio de su majestad, en que quedaba por libre y exento de esta orden, y que la presentaría a su tiempo.» Lo más seguro es que Bernabé García pensaba en el despacho real del 13 de marzo de 1650, por el que Felipe IV declara la farmacia Arte científica, y concede a los boticarios «todas las honras, preeminencias y prerrogativas que os competen, tocan y pertenecen ${ }^{15}$. Aunque entre las concesiones no figura quedar libre de las milicias, los interesados siempre que les convenía las alegaban. En la misma real cédula de 1696 quedan exentos nobles e hijosdalgos ${ }^{16}$, un estudiante o universitario por cada cien vecinos, cargos de número de la Inquisición si no exceden de cuatro, los que padezcan graves heridas o sean cojos o mancos, el maestro de gramática donde no hubiera colegio de ella, etc.

El matrimonio tuvo cinco hijos: Josefa (nace en 1698), Pedro (1700), Petronila (1714), Josefa Gabriela (1720) y Bernabé José (1723) ${ }^{17}$. Sólo le sobrevive una hija, Josefa Gabriela, que casó en torno a 1739 con Manuel Alonso Ciruelos ${ }^{18}$.

Pronto descubrimos a un Bernabé García inquieto, muy activo, preocupado por formar un patrimonio raíz del que carecía. Hasta $1710^{19}$, año en que vende la botica, realiza once escrituras de compra ${ }^{20}$, una de cesión y traspa-

14 En el AHPT no encontramos escrituras de protocolo de La Puebla de Montalbán de esos años.

15 Puerto (1997), p. 360.

16 Varias pistas en la vida de Bernabé García nos conducen a sus deseos por pertenecer a la nobleza. El origen de ello y principal fundamento parece estar en el apellido de su madre 'Cabeza de Vaca'. Además de otros libros de esta materia, en su biblioteca cuenta con la Genealogía de Bonifacio Tobar (o Tovar) que estudia «la noble y antigua casa de Cabeza de Vaca». Felipe $\mathrm{V}$ fue pródigo en la concesión de títulos de nobleza, pero no lo fue tanto con las hidalguías. En 1703 se pide a las chancillerías que sean más rigurosas con las probanzas de hidalguías (GONZÁLEZ, A.(2003), Felipe V: La renovación de España. Sociedad y Economía en el reinado del primer borbón, Pamplona, Eunsa, p. 64 y ss.). Para la real cédula de 1696, AMDP, Libro de acuerdos.

17 APDP, Libro de Bautismos.

18 En el Catastro de Ensenada (1752) se registran dos nietos de Bernabé García: Manuel de dos años y Vicenta de un mes (AHPT, Hacienda, Domingo Pérez con las signaturas 239 y 240).

19 No tenemos datos del año 1708. Faltan el protocolo y el libro de acuerdos de ese año.

20 AHPT, protocolos 5.880, 5.881 y 5.882 . 
so $^{21}$, una de concordia con el que fue su tutor ${ }^{22}$, el primer arrendamiento de la hacienda de doña $\mathrm{M}^{\mathrm{a}}$ del Prado y Ayala ${ }^{23}$, es fiador del obligado del abasto de la carne ${ }^{24}$, arrendador de las rentas decimales ${ }^{25}$, venta de la botica ${ }^{26}$, una escritura de trueque ${ }^{27}$, otra de obligado del abasto de la carne ${ }^{28}$ y un reconocimiento de censo ${ }^{29}$. Es regidor de la villa en 1700 y alcalde ordinario en 1703; además, recibe los primeros poderes del concejo para gestionar cuestiones de tributos reales, que será otra de las constantes en su vida.

$\mathrm{Su}$ objetivo fundamental en estos años — que luego prorrogará en los siguientes - es ir adquiriendo bienes raíces para formar un amplio patrimonio. Se interesa sobre todo por comprar viñas, y concentrarlas en un mismo distrito para crear una gran hacienda; más tarde se interesará también por los olivos. El mismo criterio de concentración le guía en la compra de casas o de terrenos aledaños a su vivienda.

Después de 14 años con la botica, comprobó que no le reportaba los beneficios que precisaba, y la vendió. Además, era poco compatible con sus nue5.881).

21 AHPT, protocolo 5.881.

22 El tutor se obliga a pagar a Bernabé García 1.800 reales en 4 años (AHPT, protocolo

23 AHPT, protocolos 5.882; otros arrendamientos en 5.883 y 5.884 .

24 AHPT, protocolo 5.882.

25 AHPT, protocolo 5.882. Esta actividad estuvo muy presente en su vida, y fue la causante principal de muchas de sus deudas. Escribe A. Domínguez Ortiz que los arrendadores de diezmos eran un «grupo social del que casi nada sabemos, a pesar de que movía caudales de importancia y era un posible cauce de ascensión social; una vía difícil, sin embargo, en la que los más se extraviaban porque los preceptores de diezmos hilaban muy fino» (DOMíNGUEZ, A. (1992), «Estudio Preliminar», Manifiesto universal de los males envejecidos que España padece, Madrid, Instituto de Cooperación Iberoamericana [etc.], p. XLII. En los números 274277 del Manifiesto, obra publicada en 1730, Francisco M. de Moya, su autor, expone sus opiniones sobre este tema. Comienza así el no 274 : «en cada uno de los Pueblos de estos Reynos es raro el año en que no se pierden cinco o seis Vasallos con los arrendamientos de los diezmos» p. 289). Se pueden consultar también, aunque son testimonios de finales del siglo XVIII, FERNÁNDEZ, Ma del C. y GARCÍA, M. (1996), «Memoria sobre el problema de la exacción de los diezmos», Los ilustrados toledanos y la agricultura (1748-1820). Recopilación de textos agrario, Toledo, Diputación Provincial, 195-201. ANES, G. (1999), «De diezmos y tazmías» y «Las subastas de los diezmos y otras rentas en la España de finales del Antiguo Régimen», Cultivos, cosechas y pastoreo en la España Moderna, Madrid, Real Academia de la Historia, $165-200$ y 201-240, respectivamente.

26 AHPT, protocolo 5.882 .

27 AHPT, protocolo 5.882.

28 AHPT, protocolo 5.882.

29 AHPT, protocolo 5.882 . 
vas ocupaciones, le retenía demasiado en la villa y le impedía moverse con libertad en sus negocios. En España existían leyes que prohibían a los boticarios descuidar la asistencia de sus farmacias. La Real Cédula de 13 de marzo de 1650, dirigida a los boticarios madrileños pero después vigente en toda España, ordenaba que las autoridades prohibieran a los boticarios negocios, comercios y ocupaciones que les apartaran de la atención a sus boticas. Pero ante todo fueron los proyectos sociales, económicos y políticos ambiciosos que tenía en mente, y que superaban ampliamente el estricto marco de su profesión, los que le animaron a desprenderse de la botica. La escritura de venta es del 23 de marzo de 1710; el comprador, Felipe Dávila, vecino de Domingo Pérez aunque natural de Mañosa. En la escritura leemos: «una botica surtida de botes, redomas, cajas, cacetas, alambiques, almireces y sus compuestos y simples, todo ello apreciado en 13.000 reales $\rangle^{30}$. El procurador general de la villa, quizá por temor de que el nuevo boticario se llevara la botica a otra población, se obliga a pagarle, durante seis años, 250 reales anuales por su asistencia. La botica debía estar bien surtida de todo lo necesario para la curación de las enfermedades ${ }^{31}$.

La siguiente fecha que nos parece clave en la biografía de Bernabé García es $1726^{32}$, cuando decide hacer una «información» sobre su persona y su vida ${ }^{33}$. Las razones que le llevan a ello son, nos dice, las «diferentes pretensiones que tengo intentadas con su majestad, ... para su real servicio». Bernabé García atraviesa un mal momento económico, y por sus cualidades y virtudes personales, su vida civil y religiosa ejemplares, siempre al servicio de Dios, del rey y de sus convecinos, cree merecer un cargo político en la administración real.

Hasta dicho año de 1726, los poderes que recibe Bernabé García de la villa se hacen habituales; casi parece un profesional especializado en asuntos mu-

303.000 reales los percibiría Bernabé García en el acto, y el resto en nueve plazos y pagas iguales de 1.111 reales y 3 maravedís y medio ( AHPT, protocolo 5.882).

31 Escritura del 31 de diciembre de 1710 (AHPT, protocolo 5.882). No tenemos noticias de que Bernabé García percibiera como boticario algún tipo de compensación del ayuntamiento de la villa. Muchos años después, en la sesión del ayuntamiento del 24 de febrero de 1733, se decide suspender el salario del boticario; pero luego, se cambia de opinión en la misma sesión, y se mantiene. Entonces el salario del boticario se había rebajado, desconocemos desde qué año, a 120 reales anuales (AMDP, Libro de acuerdos).

32 Debemos advertir que, en esta etapa de su vida, no tenemos datos de los años 17111713 y 1715 .

33 El 25 de septiembre de 1726 (AHPT, protocolo 5.883). El diccionario de la Real Academia Española define «Información» como las «Pruebas que se hacen de la calidad y circunstancias necesarias en un sujeto para un empleo $u$ honor». 
nicipales. El ayuntamiento siempre confía en él para negociar en Toledo o en Madrid la administración o el encabezamiento de la villa; para conseguir moratorias y rebajas de los impuestos reales por la injuria de los tiempos; para justificar los arbitrios acordados en el concejo; para defender a la villa de cualquier cargo que se le haga, ante el Honrado Concejo de la Mesta; para velar por los intereses de los vecinos en asuntos en que están involucrados eclesiásticos, etc. También los vecinos le confían sus asuntos particulares.

La compra de viñas, tierras y casas continúa ${ }^{34}$; igualmente, los remates en el abasto de la carne ${ }^{35}$ y en las rentas decimales ${ }^{36}$. Aparecen los arrendamientos (y subarrendamientos ${ }^{37}$ ) de superficies de mayores proporciones ${ }^{38}$, pero también las primeras deudas y dificultades en sintonía con la villa. Ya en 1706, la villa acude a los tribunales de justicia para exponer que el estado eclesiástico, además de poseer las mejores haciendas, no contribuye al encabezamiento por sus negocios particulares, lo que perjudica gravemente a los vecinos $^{39}$. Desde entonces, este asunto es debatido repetidamente en las sesiones del concejo, y en todas adquiere un protagonismo relevante Bernabé García, en el que recae, como dijimos, la representatividad de la villa. En 1725 se vuelve a la carga con los mismos argumentos. El estado secular, se alega ahora, soporta enteramente las contribuciones reales, y hay eclesiásticos «que adeudan por sus comercios, tratos y granjerías crecidas cantidades». La escritura relata cómo es muy perjudicado «el común por semejantes tratos [de eclesiásticos], ..., por el corto término de esta villa y hacer falta a los seculares los arrendamientos de tierras y labranza, viñas y otros heredamientos». Este año de 1725, Bernabé García ha tenido que salir fuera del término a arrendar la dehesa y labranza de Bernuy ${ }^{40}$.

34 AHPT, protocolos 5.884 y 5.883 .

35 AHPT, protocolo 5.883. Creo que el fin principal de estos remates, al menos en Bernabé García, era el disponer de un dinero líquido que la villa prestaba a los obligados para comprar el ganado en las ferias (en 1710 recibe 2.000 reales; en 1724, 1.000; en 1725, 600 y en $1727,2.500)$.

36 AHPT, protocolos 5.883 y 5.884 .

37 AHPT, protocolo 5.883.

38 AHPT, protocolos 5.884 y 5.883. En 1721 Bernabé García tiene 3 pares de bueyes (AMDP, Libro de acuerdos).

39 AHPT, protocolo 5.881. Quizá la villa quería aprovecharse del regalismo de Melchor de Macanaz, Fiscal General, que persiguió los privilegios de los eclesiásticos; cayó en desgracia en 1714. Pero el regalismo fue una constante en los borbones y estuvo presente en el ánimo de los españoles.

40 AHPT, protocolo 5.883. 
De la misma forma, encontramos en los ayuntamientos referencia a malos años de cosecha y a la situación miserable de los vecinos. En 1718, se quiere bajar el encabezamiento, y ajustarlo a la «proporción de la vecindad y cortas haciendas que poseen y gozan los vecinos, las muchas cargas y gravámenes de censos, tributos y memorias a que están afectos e hipotecados, lo calamitoso de los tiempos, los cortos valores de los frutos ....»11. En 1722, la villa comparece ante el corregidor e intendente de Toledo y su provincia, y describe «el mísero estado en que los vecinos se hallan ... Y cómo no puede esta villa pagar el encabezamiento si no es logrando una considerable, como necesaria, baja y moderación de su importe» ${ }^{42}$. En 1726, hay langosta. El ayuntamiento manda que se reconozca el término y se aren y se den las labores necesarias en las tierras con langosta. Se acuerda que para coger la langosta se organicen grupos de vecinos, con ropas adecuadas, al frente de los cuales haya personas que los dirijan con orden para evitar daños mayores. El concejo decide, para «aplacar la ira de Dios», y para que les conceda agua y les libre de la plaga de langostas, hacer un novenario y rogativa; ponen por intercesores y abogados al Santísimo Cristo de la Misericordia, al Patriarca San José y a San Antonio de Padua ${ }^{43}$. A toda esta situación hay que añadir el pleito que originó la capellanía fundada en 1718, que destapó un malestar latente entre los vecinos contra estas fundaciones. Durante siglos se habían ido fundando memorias, fiestas, vínculos, capellanías, etc, que favorecían a la iglesia (y a sus miembros) y perjudicaban al común de los vecinos. Hasta donde sabemos, a partir de la segunda mitad del siglo XVII y la primera del XVIII, las capellanías colativas aumentan en Domingo Pérez. Estas capellanías segregaban importantes bienes raíces, que se convertían en espirituales; es decir, no contribuían a la Real Hacienda. Sus rentas se destinaban al sustento de un capellán, que se obligaba a celebrar misas u otras cargas litúrgicas por el fundador y su familia ${ }^{44}$. Se entiende, por tanto, que la villa proteste esta capellanía ante

41 AHPT, protocolo 5.884.

42 AHPT, protocolo 5.883. Quizá Bernabé García conociera la Carta al Rey de España del Cardenal Belluga, de 1721. En ella, Belluga pide la paz para un país que vive en una situación límite y mísera (GIL, A. (1984), «Política y Sociedad», Historia de España, t. VII, Barcelona, Labor, 175-320, p. 208 y ss.).

43 AMDP, Libro de acuerdos.

44 Teruel, M. (1993), Vocabulario básico de la historia de la iglesia, Barcelona, Crítica, 1993, pp. 63-69. 
el Consejo de la Gobernación del Arzobispado de Toledo en $1718^{45}$, y, como no se la escucha, acuda después al Consejo Real de Madrid en $1719^{46}$.

Observamos que cada vez hay una mayor identificación entre Bernabé García y la villa. Los problemas de la villa suelen coincidir con los de Bernabé García; o viceversa, los problemas de Bernabé García son los mismos que importan a la villa.

El 3 de junio de 1720 está enfermo y redacta su primer testamento ${ }^{47}$.

Y el 25 de septiembre de 1726 comienza la referida «información». Este día, Bernabé García comparece ante el alcalde mayor de Domingo Pérez, por cuanto tiene «diferentes pretensiones» solicitadas a su majestad. De su puño y letra escribe ocho preguntas que irán respondiendo seis testigos. Cuatro de los testigos son labradores (uno de ellos hidalgo), otro un maestro albañil y el sexto el médico de la villa. Las noticias que nos transmiten sobre la vida y la personalidad de Bernabé García son del mayor interés, pero debemos tomarlas con cautela porque los testigos han sido seleccionados por el propio protagonista.

La primera pregunta aclara que Bernabé García ha ocupado el cargo de alcalde ordinario los años 1703, 1712 y 1717; el de regidor los de 1700 y 1713; y el de procurador general los de 1718 y 1722. En todos estos años, Bernabé García ha administrado justicia con igualdad, conforme a derecho, sin falta ni exceso, mirando al servicio de Dios, del Rey y a la paz de los vecinos ${ }^{48}$.

La segunda pregunta informa de que por las propuestas, máximas políticas y económicas y agencias de Bernabé García, ocupara cargo municipal o siendo repúblico, la villa ha mejorado en calidad de vida y en convivencia pacífica de sus vecinos. En los repartimientos de los impuestos reales y municipales, Bernabé García ha buscado beneficiar a los pobres y evitar las disensiones entre los ricos, implantando el sistema «sueldo a libra» ${ }^{49}$. Se podría pensar que Bernabé García aplicó en la villa un «reformismo» equiparable al de los borbones en

\footnotetext{
45 AHPT, protocolo 5.884.

46 AHPT, protocolo 5.884 .

47 AHPT, protocolo 5.884 .
}

48 Todos los testigos confirman lo preguntado. Don José Maldonado, médico de la villa, añade que Bernabé García es persona «de toda integridad, rectitud y celoso del bien público, y enemigo de perjudicar a terceros».

49 Sueldo a libra o sueldo por libra: «Frase con que se explica la proporción con que se reparte alguna cosa, según lo que corresponde al principal o derecho» (Real Academia Española, Diccionarios de Autoridades, ed. facs. (ed.orig. 1726), 3 vols., Gredos, 1990). En el Diccionario de la R.A.E. «Derecho sobre un capital determinado, en proporción de 1 a 20 ».

Los testigos coinciden en que Bernabé García ha puesto los medios para que el pueblo se gobierne «perpetuamente» en paz. 
España: mejor organización del municipio, mayor equilibrio y justicia en los repartimientos de tributos y dosis de regalismo en la medida en que se quiere que los eclesiásticos pierdan sus privilegios y que contribuyan en los impuestos reales. De lo que no tenemos dudas es de que Bernabé García aportó rigor, firmeza y orden en los asuntos municipales.

La tercera pregunta descubre el lado religioso de Bernabé García ${ }^{50}$ :

- Para la veneración del culto divino mandó hacer a su costa el retablo del altar mayor de la iglesia, y para su adorno mandó ejecutar la imagen de Nuestra Señora de la Concepción, la imagen de San Bernabé y contribuyó con la cuarta parte de la imagen de San Josés1. También corrió por su cuenta la colocación de las tres imágenes en el altar mayor, las fiestas y los predicadores que trajo para la celebración.

- Propuso en un cabildo de la cofradía del Santísimo Sacramento que se sacasen cuatro hachas para celebrar el renuevo todos los jueves del año. Con ello pretendía mayor reverencia de los fieles y moverlos a más devoción.

- En otro cabildo de la misma cofradía, planteó que la procesión de Minerva se celebrase todos los terceros domingos del mes por dentro de la iglesia, para que los devotos «ardiesen más en su devoción» y gozasen de las indulgencias.

- Consiguió que los capitulares de la villa asistiesen a las procesiones «votivas y comunes, como son letanías y otras generales». Con ello, las procesiones ganaron en solemnidad.

50 Durante el reinado de Felipe V la mentalidad religiosa de los españoles no experimenta ningún cambio sustancial. Ofrecemos la opinión de un extranjero, del tiempo de nuestro protagonista, sobre la fe de los españoles: «Pero aunque alabo su templanza [de los españoles], nunca se me ocurrirá aprobar su fanatismo. Si existiera en el terreno religioso algo parecido a la embriaguez, me temo que la suya excedería cualquier medida. So pretexto de devoción, he visto entre ellos a las gentes, incluso a personas por otra parte razonables, cometer los mayores disparates. No es raro ver a sus hidalgos, tanto a los de mayor alcurnia como a los de los rangos inferiores, arrodillarse si se encuentran con un sacerdote en plena calle, tomar el bajo de su sotana y saludarle alzando la vista, como si viesen en él la garantía de su salvación.» (DEFOE (2002), Memorias de guerra del capitán George Carleton. Los españoles vistos por un oficial inglés durante la Guerra de Sucesión, Universidad de Alicante, p. 278).

51 No sabemos lo que supuso el retablo del altar mayor. La imagen de Nuestra Señora de la Concepción costó 4.040 reales, y ya la tenía en su casa en junio de 1720; en la imagen de San Bernabé gastó 397 reales y en la cuarta parte de la de San José, 300. Retablo e imágenes se pueden contemplar hoy en la iglesia de Domingo Pérez. 
- Ha servido varias veces como mayordomo en todas las cofradías de la iglesia.

- Con sus limosnas ha contribuido a que la iglesia adquiriera un terno blanco de damasco, un estandarte, una capa de coro, un palio y a que la Custodia del Santísimo Sacramento se dorara.

Además de lo dicho, Bernabé García fue el principal impulsor en la erección de la capilla de San Antonio de Padua en la iglesia ${ }^{52}$. Por todos estos méritos, el arzobispo de Toledo le concede dos sepulturas en propiedad, en lugar privilegiado de la parroquia, el 7 de diciembre de $1724^{53}$.

Las dos siguientes preguntas desvelan el comportamiento de Bernabé García en los años de la Guerra de Sucesión ${ }^{54}$ :

- En 1703, al principio de la guerra ${ }^{55}$, siendo alcalde, exhortó a los vecinos y, particularmente a los mozos solteros, para que sirvieran en los ejércitos de su majestad; incluso se ofreció servir él mismo.

- Trabajó todo lo que estuvo en su mano por las quintas de soldados ${ }^{56}$.

- Contribuyó en los donativos voluntarios, que durante la guerra se pidieron, con mayor porción que otros vecinos ${ }^{57}$.

— Dificultó el tránsito de las tropas enemigas, exponiendo su vida a varios peligros $^{58}$.

52 Los trámites para la edificación de la capilla se inician en 1722, año en que Bernabé García es procurador de la villa. Todo el proceso de la construcción de la capilla se puede seguir en el ADT, Sección de Reparación de templos, Legajo 14, Expediente 14. También en los Libros de acuerdos del AMDP y en escrituras de protocolos del AHPT de estos años.

53 AHPT, protocolo 5.883.

54 El médico de la villa no podrá responder a estas preguntas porque por entonces no vivía en Domingo Pérez. Se limita a contestar que lo ha oído y lo tiene por cierto.

55 En Europa, por motivo de la sucesión a la corona española, hay guerra desde 1702, pero en la península no empieza hasta 1705 (LEÓN, V. (2002), «Estudio Preliminar», Memorias de guerra del capitán George Carleton. Los españoles vistos por un oficial inglés durante la Guerra de Sucesión, Universidad de Alicante, 9-81, p. 40).

56 En 1703, siendo alcalde, lleva a cabo un reclutamiento de soldados en la villa, pero cuando se va a comunicar a los dos vecinos que les ha tocado, ya han huido (AMDP, Libro de acuerdos). También participa en 1712, es igualmente alcalde, en el reclutamiento de soldados de infantería (AMDP, Libro de acuerdos). Véase sobre este asunto DomínguEZ, A. (1984), Sociedad y Estado en el siglo XVIII español, Barcelona, Ariel, p. 20 y DomíngUEZ (1992), p. LIV.

57 Los donativos eran tributos directos que gravaban a todos los vecinos según su riqueza (DOMíNGUEZ (1992), pp. XXVII-XXVIII). 
— En 1706, con mucha gente de Domingo Pérez y de otros pueblos trató de impedir el paso al conde de San Juan, que bajaba a Portugal con su tropa ${ }^{59}$.

- En 1703, ante las urgencias de la guerra, sacó, con la prontitud que las circunstancias requerían a los vecinos más acomodados, el dinero que la villa debía pagar a su majestad; y después cumplió con esos vecinos.

Con la sexta pregunta se quiere saber si Bernabé García es merecedor de un cargo político o económico que le concediese su majestad; y si lo desempeñará con el celo que siempre ha manifestado a su real servicio ${ }^{60}$.

La séptima pregunta se interesa por la situación económica de Bernabé, su deteriorado caudal y sus grandes empeños; si las deudas tienen su origen en el poco fruto que ha cogido y en las muchas obligaciones de su cargo ${ }^{61}$.

58 El tercer testigo relata de forma pormenorizada un lance en que peligró la vida del protagonista: « ... siendo el testigo alcalde el año 1708, habiéndose interpuesto el dicho Bernabé García con unos oficiales de un regimiento que transitaba y querían alojarle, sin tocar aquí [en Domingo Pérez], y no queriendo pasar si no es dándoles un doblón de a ocho, porque no le aprontaba [Bernabé García] con la brevedad que querían, le ajaron y puso uno una pistola a los pechos, dándole un gran golpe, que milagrosamente le pareció al testigo no disparase y le quitase la vida. Sin otros males términos que usaron precisando a que se les diese injustamente [el doblón], lo que no pudieron resistir por el peligro en que se ponían, y porque el pueblo no padeciese dicha invasión»»

59 En 1706 Felipe $\mathrm{V}$ se encuentra en una situación difícil porque es atacado por el este (Zaragoza se une al Archiduque) y por el oeste (Portugal). Los aliados avanzan desde Portugal hacia Madrid. Felipe V huye de Madrid en junio y el Archiduque se proclama rey (DomínGUEZ (1984), pp. 25-36).

60 Todos están de acuerdo en que es apto para el cargo y que lo desempeñará con extraordinario celo público. El médico de la villa parece ir más allá y nos presenta a Bernabé García con cualidades de arbitrista o proyectista -término preferido en el siglo XVIII-, por cuanto le ha escuchado remedios provechosos para solucionar los problemas de España: «Cree que el susodicho, por sus operaciones, es benemérito para obtener cualquier empleo o cargo que su majestad fuese servido conferirle, en lo político y económico, mediante ser hábil, capaz, de buena intención, práctico y de economía; y muy celoso del servicio del rey y utilidad común a la monarquía, por haber visto y tocado lo que ha hecho en esta villa, todo cuanto ha cabido en su alivio. Y le ha oído muchas proposiciones en utilidad de la monarquía, dignas de ser observadas». Por otro lado, desde la primera pregunta, los testigos reiteran el excesivo celo de Bernabé García en los asuntos reales y públicos. Nos recuerda los juicios de San Felipe sobre don Francisco Ronquillo, conde de Granedo y presidente del Consejo de Castilla: «hombre de singular fidelidad y amor al Rey, tanto que se propasaba su celo y por eso adquirió fama de demasiado rígido» (cito por DEFOE (2002), n. 68, p. 289).

61 Todos confirman la mala situación económica de Bernabé García. 
El interrogatorio se cierra preguntando por la vida y las costumbres de Bernabé García ${ }^{62}$.

La Información acaba con las palabras del alcalde mayor acreditando a los testigos, coincidiendo con ellos y aprobando toda la declaración ${ }^{63}$. Para nada nuestro protagonista ha recordado ni una sola vez su labor primera de boticario. Una profesión irrelevante para Bernabé García, con escasa proyección social, que poco o nada podía añadir a sus méritos políticos y económicos.

En la siguiente etapa que vamos a examinar de su vida, hasta $1743^{64}$, encontramos a un Bernabé García agobiado por deudas y censos. Atravesó momentos muy críticos, hasta el punto de que, tal vez, estas dificultades fueran una de las causas que le llevaron a otorgar poder para testar en marzo de $1739^{65}$. Dos años después, cuando parece recuperado, enferma, y no puede asistir al ayuntamiento para tomar posesión de la vara de alcalde ${ }^{66}$. En abril de 1743, con 70 años, nos habla de sus abundantes deudas, de su edad avanzada, de sus escasas fuerzas, razones que le obligan a ceder todos sus bienes a la hija y al yerno ${ }^{67}$. Vuelve a estar enfermo en mayo de este mismo año, y hace testamento. Sin embargo, Bernabé García, descargado de responsabilidades y alejado del ajetreo de los negocios, vivirá todavía algunos años más.

Bernabé García no consiguió el cargo de funcionario que pretendía con la información de 1726. Continuó representando a la villa aunque más moderadamente. Su actividad frenética anterior experimenta un considerable frenazo. En este periodo realiza una única compra ${ }^{68}$, dos ventas ${ }^{69}$ y un arrendamiento $^{70}$. Pero no tenemos noticias de escrituras de arrendamientos de diezmos ${ }^{71}$,

62 También coinciden todos los testigos en las buenas costumbres y en la vida ejemplar del protagonista.

63 La Información y Aprobación del alcalde mayor son del 30 de octubre de 1726.

64 No tenemos escrituras de protocolos del escribano de Domingo Pérez de los años $1730-1734$ y 1742 .

65 El poder es del 5 de marzo de 1739, AHPT, protocolo 5.886.

66 AMDP, Libro de acuerdos, 21 de enero de 1741.

67 Esta escritura de convenio y traspaso de bienes entre Bernabé García y su yerno e hija se hace el 5 de abril de 1743 (AHPT, protocolo 5.887).

68 AHPT, protocolo 5.883.

69 AHPT, protocolos 5.883 y 5.886 .

70 AHPT, protocolo 5.883.

71 Sin embargo, a través de escrituras de obligación sabemos que al menos administraba la porción del diezmo que tocaba, como partícipes, a distintos curas de Domingo Pérez durante los años 1726-1735. También conocemos, por el libro de acuerdos de 1730, que Bernabé García hace llegar al ayuntamiento una cédula real que manda que en los repartimientos de 
de abasto de la carne, del arrendamiento de la hacienda de doña Mariana del Prado, de otros arrendamientos y subarrendamientos. En este tiempo está preocupado por conservar y afianzar sus propiedades, y se dedica a plantar olivos y vides, y a protegerlos de los ganados ${ }^{72}$.

Si Bernabé García no alcanzó el puesto en la administración real, sí ascendió en el rango municipal, lo que en algo compensaría su orgullo y vanidad personal. Además de procurador general de la villa en 1727, y de alcalde ordinario en 1728 y 1741, desempeñó el cargo de alcalde mayor los años 1734, 1735 y 1736. Este cargo era de designación directa del Conde de Orgaz, el señor de la villa, que nombra a Bernabé García alcalde mayor el 30 de noviembre de 1733, y lo destituye el 20 de octubre de 1737. Como vemos, estuvo en el cargo más de tres años, y quizá hubiese podido continuar más tiempo, pero sus dificultades económicas y sus diferencias con algunos vecinos y la justicia de esos años lo impidieron.

En 1735, dos vecinos hablan mal de Bernabé García al Conde de Orgaz y éste le desposee del título de alcalde mayor. El asunto se aclara y el conde le restituye en el cargo ${ }^{73}$.

Los conflictos entre los vecinos no acaban ahí. Todo el año 1735 es un pulso con los alcaldes ordinarios de 1734. Era normal que el equipo municipal que entraba pidiera cuentas al del año anterior, pero las malas cosechas acumuladas y el empobrecimiento general tenían enrarecido el ambiente de la villa, y favorecía el enfrentamiento entre los vecinos. El 16 de marzo de 1736 el juez de residencia que examina los cargos municipales de 1733-1735, encuentra irregularidades en los repartimientos para los gastos de la villa de 1734, pero ninguna en los años 1733 y $1735^{74}$.

alcabalas no se tenga en cuenta la cantidad en que se remata las rentas decimales, sino sólo aquello que se venda de esas rentas.

72 En Domingo Pérez, como en los pueblos de la zona, se produce a lo largo de la primera mitad del siglo XVIII una crisis cerealista. Esto hace que muchos agricultores se decidan por el cultivo de olivos y viñas como más seguros y rentables. El vino y el aceite eran productos cada vez más demandados por Madrid, un mercado gigantesco, próximo y bien comunicado. Pero la crisis cerealista también provocó que otros agricultores (y ganaderos) buscaran soluciones en el ganado lanar y porcino, con lo que su número creció. Con estos elementos en escena, los conflictos no se hacen esperar (MARTín, F. (2001), «A propósito de las Ordenanzas de Santa Olalla de 1623 y de un litigio entre ganaderos y hacendados del siglo XVIII», Anales Toledanos, XXXVIII, Diputación Provincial, 83-112).

73 AMDP, Libro de acuerdos.

74 AMDP, Libro de acuerdos. 
En 1737 Bernabé García sigue siendo alcalde mayor, pero un incidente con la justicia de ese año va a provocar su salida del cargo. Del ayuntamiento del 30 de junio, Bernabé García sale muy molesto porque alcaldes, regidores, procurador general y demás capitulares presentes, no han consentido que figure en el Padrón General solicitado por la Chancillería de Valladolid con el 'don' delante de su nombre, como aparece en el título de alcalde mayor que le concedió el Conde de Orgaz ${ }^{75}$. A raíz de este suceso el procurador general de la villa escribe varias cartas al conde pidiéndole el cese de Bernabé García como alcalde mayor. En octubre, el escribano de la villa le comunica el decreto del Conde de Orgaz, por el cual debe dejar la vara de alcalde mayor ${ }^{76}$.

Las dificultades económicas de Bernabé García durante este periodo de su vida parece que le superan y le obligan a ceder sus propiedades a su yerno e hija. Es verdad que cuando decide dar el paso tiene 70 años y se encuentra debilitado por las enfermedades; pero igualmente es cierto que todavía vivió casi diez años más, por lo que podemos pensar que lo que más necesitaba era paz y alejarse de la agitada vida que hasta entonces había llevado. Si realizamos un recorrido por estos años, veremos los distintos obstáculos a los que Bernabé García tuvo que enfrentarse, cómo los supera y en qué condiciones alcanza el año 1743.

En noviembre de 1728 firma una escritura de obligación por la que se compromete a devolver al pósito de la villa cien fanegas de trigo. Sin embargo, una anotación en la misma escritura, del 18 de septiembre de 1730, avisa de que se anuló la partida «por no haber sacado del pósito las cien fanegas de trigo ...., y no está obligado a pagarlas ${ }^{77}$. Desconocemos qué pudo pasar, pero

75 AMDP, Libro de acuerdos. Nos cuenta el capitán Carleton que «quienes reciben el don» son los nobles (DEFOE (2002), p. 216). Y José de Cañizares, dramaturgo contemporáneo a Bernabé García, en su comedia El picarillo en España, pone en boca de uno de los personajes: «Es doña Inés/ No la quite usté el dictado/ Del don, que ya empieza a andar/ Entre arneros y estropajos» (Dramáticos posteriores a Lope de Vega, Tomo segundo, Atlas, 1951, p. 537).

76 AMDP, Libro de acuerdos.

77 AHPT, protocolo 5.883. La función principal del pósito era prestar trigo a los labradores para que pudieran sembrar cada año. Los labradores y aquellos otros vecinos que recibían el préstamo hacían escrituras de obligación. En ellas se comprometían a devolver el trigo recibido más las creces (medio celemín por fanega), para el día de Santiago, 25 de julio. En los años de carestía, el trigo del pósito se destinaba a paliar el hambre de los vecinos. Pero en muchas ocasiones el pósito se convertía en un recurso muy socorrido por las autoridades municipales. Se acudía a él para vender su trigo y solucionar las distintas necesidades que surgían, como proporcionar los préstamos al obligado de la carne o pagar cualquier deuda urgente de la villa. Con demasiada frecuencia, los pósitos eran dominados por las oligarquías rurales 
estas fanegas de trigo sí podían ser útiles a Bernabé García por cuanto desde 1727 tiene arrendada la labranza de Rojas por 8 años y cien fanegas de pan por mitad cada año ${ }^{78}$. Además, como obligado de la carne que cumplía en 1728 , recibió del ayuntamiento un préstamo de 2.500 reales que debía devolver en doscientas fanegas de trigo; aunque luego, al parecer, los alcaldes prefirieron el dinero ${ }^{79}$. A pesar de todo, el pósito llevaba un control riguroso por parte de los Condes de Orgaz y de las autoridades de la villa, y resultaba muy difícil realizar desfalcos de esas características.

De febrero de 1729 es otra escritura por la que se obliga a pagar 5.087 reales en ese mismo año ${ }^{80}$. Este año de 1729 se le registra una deuda menor de 126 reales $^{81}$. También, el 18 de octubre de ese año, como alcalde que fue en 1728 , se compromete a devolver cincuenta fanegas de trigo al pósito, con las creces correspondientes, para Santa María de Agosto de $1730^{82}$.

El 27 de junio de 1733 la justicia descubre que ha impuesto un censo de 4.800 reales de principal que no ha declarado ${ }^{83}$. En la sesión de ayuntamiento del 3 de noviembre de 1733, presenta un traslado autorizado por el que se le exonera del pago del 6 por ciento a las reales alcabalas, de los 9.800 reales que sobre su hacienda impuso en censos los años 1729 y 1730. El concejo se opone a ello, y piensa recurrirlo ${ }^{84}$.

Los embrollos con los censos de Bernabé García no terminan, y en marzo de 1736 no se entiende con la justicia de la villa en la cantidad que debe desembolsar en concepto de alcabalas de heredades por un censo que impuso.

que los utilizaban en su servicio. Para evitar esto se creó en 1751 la Superintendencia General de Pósitos. A partir de entonces creció el número de pósitos y mejoró su administración. A fines del siglo XVIII y principios del XIX, por motivos de las guerras y los gastos militares, el estado recurrió a las reservas de los pósitos, lo que les causó mucho daño (DomínGUEZ (1984), pp. 418-419).

78 AHPT, protocolo 5.883 .

79 AMDP, Libro de acuerdos de 1727.

80 AHPT, protocolo 5.883.

81 AHPT, protocolo 5.885 .

82 AHPT, protocolo 5.885 .

83 Bernabé García explica que si no ha «dado cuenta a los señores justicias de esta villa ha sido por hacer muy corto tiempo que ha que impuso dicho censo, y no hacer casi medio año del que va corriendo». Quiere que no se vea mala intención en ello porque siempre ha sido una persona honrada que ha buscado el bien del común (AMDP, Libro de acuerdos).

84 AMDP, Libro de acuerdos. Escribe A. Domínguez Ortiz: «La fuerte presión fiscal aguzaba el ingenio para sustraerse a ella, al menos en parte; ... El abuso llegó a tal punto que se hizo necesario revocar muchas de estas concesiones [de cargos en la administración]» (DOMÍNGUEZ (1984), p. 72). 
Media el Conde de Orgaz, y determina que pague a la villa 300 reales en seis plazos de 50 reales cada uno ${ }^{85}$. Por una escritura del 20 de junio de 1736 nos enteramos de que ha abonado más de 17.000 reales, los mismos en los que fue alcanzado por la tutela de un sobrino ${ }^{86}$; pero todavía debe 3.000 reales y Bernabé García paga con un majuelo ${ }^{87} .1736$ fue un año desdichado para Bernabé García. El 19 de septiembre otorga una escritura de obligación por 14.930 reales. Los 29 de septiembre de cada año, 1737 será el primero, desembolsará 1.500 reales hasta saldar la deuda. Si él muriera, la obligación continuará en su hija ${ }^{88}$.

En agosto de 1737, los alcaldes de Domingo Pérez quieren cobrar a Bernabé García el dinero que debe a la villa y el trigo que adeuda al pósito. No lo pueden llevar a cabo por la esterilidad del año y, por tanto, hallarse imposibilitado. Deciden aplazar el cobro para agosto de $1738^{89}$.

Bernabé García no ha cumplido con alguno de los plazos acordados en 1736. Para evitar procedimientos ejecutivos contra su hacienda y otros daños mayores, su consuegro, el 14 de julio de 1740, firma una escritura de obligación; por ella se responsabiliza de la deuda de Bernabé García ${ }^{90}$.

Del 22 de agosto de 1741 es el testamento de un trabajador de Bernabé García. En él declara que su amo le debe «diversa cantidad de maravedíes del mucho tiempo que ha asistido en su casa, trabajando diariamente en lo que ella ocurría» ${ }^{91}$.

En 1743, la situación económica de Bernabé García es más que comprometida $^{92}$. Todos sus bienes se valoran en 143.807 reales, pero de ellos hay que bajar por deudas, censos y otros derechos 91.518 reales (63' 63 por ciento); por lo que quedan libres 52.289 reales (36’36 por ciento). Los 91.518 reales se distribuyen así:

85 AHPT, protocolo 5.886 .

86 Bernabé García pagó 2.000 reales en tinajas y el resto en dinero (AHPT, protocolo 5.886).

87 AHPT, protocolo 5.886. El majuelo volvió a ser de Bernabé García en 1743 (véase el codicilo del 16 de marzo de 1751; AHPT, protocolo 5.888).

88 Para la seguridad de la escritura, Bernabé García hipoteca la casa de la plaza de la villa, la heredad de cepas y olivas del Cerro del Mono y los majuelos de las Tapias y de los Dos Caminos (AHPT, protocolo 5.886).

89 AMDP, Libro de acuerdos.

90 AHPT, protocolo 13.778.

91 AHPT, protocolo 5.887.

92 Estos datos están sacados de la escritura de convenio y traspaso de bienes, del 5 de abril de 1743, entre Bernabé García y Manuel Alonso Ciruelos y Josefa García Bermúdez, su mujer (AHPT, protocolo 5.887). 
- De los principales de los censos: 18.150 reales (19'83 por ciento).

- De las deudas: 48.069 reales $(52,52$ por ciento).

— De los derechos de su hija y yerno: 25.299 reales (27'64 por ciento).

Por los censos comprobamos que prácticamente todos los bienes raíces y las mejores haciendas están hipotecadas. Las deudas nos explican, en cierta medida, los modos de actuar, a veces desesperados, de Bernabé García; cómo sus apuros económicos vienen de atrás, cómo se van acumulando y cómo para saldar unas deudas se contraen otras nuevas ${ }^{93}$. También quedan reflejadas las deudas contraídas como arrendador de rentas decimales y las deudas como arrendador de tierras de labor, viñas y olivos ${ }^{94}$. Por último, hay una cantidad importante de 21.710 reales que debe a su consuegro, de distintas retribuciones que éste ha hecho en nombre de Bernabé García 95.

A partir de 1743, Bernabé García se retira de los negocios y de la intensa vida que hasta entonces había llevado ${ }^{96}$. Desde ahora, su hija y su yerno están obligados a mantenerle y vestirle diariamente hasta que muera, «con la decencia correspondiente a su persona y carácter» ${ }^{97}$. Nada quiere saber de su vida anterior, y menos de los acreedores que «en ningún tiempo ni en manera alguna ... le han de molestar ni pedir nada»; de ellos se ocuparán el yerno y el consuegro ${ }^{98}$.

93 De 1741, cuando fue alcalde ordinario, son 6.200 reales que dejó a deber al administrador de tributos reales, 300 reales del resto del censo de villazgo que tampoco terminó de pagar, 500 reales del pósito, etc. Todo este dinero, que no era suyo pero que como alcalde disponía de él, le sirvió en su momento para saldar las deudas más acuciantes y para calmar a los acreedores más impacientes; pero, claro, originó nuevas deudas y nuevos acreedores. Por ejemplo, el 1 de febrero de 1745, el yerno y la hija se obligan a retribuir 6.200 reales que Bernabé García dejó sin satisfacer cuando fue alcalde en 1741 (AHPT, protocolo 5.887).

947.570 y 9.764 reales, respectivamente.

95 Quizá el matrimonio de su hija con Manuel Alonso Ciruelos fuera el mejor negocio de su vida; al menos, gracias a él, salvó su casa de mayor ruina. Al final de la escritura de cesión y traspaso de bienes, entre las condiciones, una de ellas establecía que sobre las deudas de 48.069 reales de Bernabé García, 37.810 reales corresponde pagar a Gabriel Ciruelos y 10.259 reales a su hijo.

96 Asegura A. Domínguez Ortiz que «el ideal de todo negociante afortunado seguía siendo abandonar los negocios, comprar bienes raíces, fundar mayorazgos, entroncar con familia hidalga y hacerse perdonar el origen de su fortuna» (cito por CASTRO, A. (1974), Cervantes y los casticismos españoles, Madrid, Alianza, p. 177). Pero, como sabemos, Bernabé García no fue un «negociante afortunado».

97 Primera de las condiciones que Bernabé García pone en la citada escritura de convenio y traspaso de bienes a su hija y yerno.

98 Segunda condición de la citada escritura de convenio y traspaso de bienes. 
La documentación que nos llega en estos años de Bernabé García es casi más de testamentos y de codicilos que de otro tipo ${ }^{99}$. Sin embargo, los vecinos afectados en el juicio de residencia, todavía confían en él en 1745 para que les defienda de los posibles cargos que el juez les haga ${ }^{100}$. También el concejo confía en él en 1746, y le nombra comisionado para que negocie con los eclesiásticos de la villa. En virtud del nuevo concordato, los eclesiásticos debían pechar como los legos, una reivindicación de la villa desde los primeros años del siglo ${ }^{101}$. En 1748 es llamado al ayuntamiento para que, como vecino que mejor conoce el asunto que se debate, asesore a la justicia en el pleito que tiene contra el Consejo de la Gobernación del Arzobispado de Toledo. ${ }^{102}$. Este año de 1748 , vende un cuartillo de prado por 300 reales ${ }^{103}$.

No obstante, desde 1745 el pulso le tiembla, y así se refleja en las escrituras que firma. El primer codicilo es del 16 de marzo de $1751^{104}$. En él encontramos un Bernabé García sincero, que manifiesta su amor y afecto por su hija, nieto y sobrino; pero también expresa un amargo reproche hacia su yerno. A su hija le manda casi 3.000 reales más para su dote ${ }^{105}$, además de lo que haya rentado el majuelo del Grullero desde $1743^{106}$. A su nieto le manda tal vez lo que más amaba: un cristo de marfil y cien libros firmados con su nombre y apellidos. Con respecto a los libros, el abuelo desea que los estudie cuando sea mayor «para que sea hombre». Bernabé García sabía del poder de la lectura, de su eficacia para liberarse de ataduras como la tradición y la cultura oral. El estudio, la lectura hace hombres libres, independientes, instruidos, mejor preparados para desenvolverse en la sociedad, y todo ello es lo que

99 Recordemos que el primer testamento que hizo fue el 3 de junio de 1720. El 5 de marzo de 1739 otorga un poder para que puedan testar por él. El segundo testamento es del 15 de mayo de 1743. Y, finalmente, realiza dos codicilos: el 16 de marzo de 1751 y el 26 de noviembre de 1752 .

100 Escritura del 30 de diciembre de 1745 (AHPT, protocolo 5.887).

101 Ayuntamiento del 11 de febrero de 1746 (AMDP, Libro de acuerdos). Se debe referir al concordato del 26 de septiembre de 1737.

102 La disputa es por una gotera de la iglesia, que desde Toledo se piensa que la causaron las obras de la capilla de San Antonio de Padua, promovidas por la villa y finalizadas en 1730 (Escritura del 30 de septiembre de 1748, AHPT, protocolo 5.888).

103 Escritura del 22 de noviembre de 1748, AHPT, protocolo 5.888.

104 AHPT, protocolo 5.888.

105 «Declara que de efectos que no entraron en dicha escritura [de convenio y traspaso de bienes de 1743], y que después ha vendido y cobrado, ha gastado en la casa de su yerno e hija» 2.905 reales. Ahora «quiere que sirvan de caudal a su hija».

106 «Declara que desde el año 1743, su yerno e hija han disfrutado del majuelo del Grullero, y quiere que lo que se considere de arrendamiento se conceptúe por caudal de su hija». 
quería para su nieto ${ }^{107}$. Con su sobrino Manuel Ruiz de Ahijado tuvo una sana y prolongada relación. Se entendieron bien y solucionaron sus asuntos sin recurrir a pleitos. Quizá representó para Bernabé García el hijo varón que le hubiese gustado tener. Le manda unos libros, el espadín, el bastón con puño de plata y la peluca «si le hiciese al caso». Para su yerno es la desaprobación. Le echa en cara que no haya cumplido con lo acordado en 1743 en lo tocante a su manutención y vestido: «Declara que dicho año de 1743, sus bienes libres los cedió y donó a su yerno e hija, con el cargo de que le vistiesen y mantuviesen. Lo que su yerno no ha cumplido en la forma que se obligó y como correspondía a la persona del otorgante. Lo cual, para los efectos que haya lugar y descargo de su conciencia, hace esta declaración» ${ }^{108}$. A pesar de todo, Bernabé García parece que tiene en cuenta los difíciles años que se están viviendo cuando modifica, en el codicilo de 1751, algunos puntos del testamento de 1743. Lo más llamativo es la reducción de 200 misas por su alma a $63^{109}$. También suprime las misas de cabo de año y de función de honras, tal como las dispuso en $1743^{110}$. La voluntad de Bernabé García es que su cuerpo «se amortaje en hábito de San Francisco»"11, y se introduzca en un

107 «Manda a Manuel Francisco Ciruelos, su nieto, el Cristo de marfil, peana y cruz de ébano, junto con cien libros firmados de su nombre y apellido, para que se dedique, en la edad correspondiente, a estudiar para que sea hombre.» Quizá Bernabé García tenía un concepto del hombre cercano al de Feijoo, según la interpretación de Americo Castro: «su valor consistirá ... en su facultad razonadora y comprensiva que le permita despojarse de los errores que infestan la mente del vulgo. Su ideal será, pues, la ciencia y el conocimiento» (CASTRO, A. (1973), Españoles al margen, Madrid, Júcar, p. 65).

108 A Bernabé García le gustaba vestir a la moda y con tejidos de calidad. En el codicilo de 1751 se alude a un «vestido nuevo de carro de oro, con botonadura de plata y de marfil» y a una «chupa de gorgorán de Florencia», todo valorado en 600 reales; una capa de grana valorada en 400 reales; 90 reales de tres pares de medias y 46 reales de pagar al sastre. Con todo, Bernabé García no parece estar contento y se lo reprocha a su yerno. Pero debemos entender también al yerno. La villa agudiza sus dificultades económicas después de 1743, y con ella sus vecinos. Manuel Alonso Ciruelos tiene que vender un majuelo en 1749 para pagar deudas. A finales de 1750 y principios de 1751 anda en pleitos por negarse a reconocer un censo. En 1751 vende una tierra frontera. En 1752 declara cinco censos por un importe total de 18.150 reales. Podríamos continuar pero únicamente referiremos la venta, en 1766, del Cerro del Mono, su mejor heredad.

109 En el testamento de 1720, las misas por su alma eran 500. La disminución del número de misas se puede interpretar como un indicador de la situación económica de Bernabé García.

110 En 1743 debían celebrarse con diácono, subdiácono, vigilia y responso, y con la ofrenda de media fanega de trigo y media arroba de vino.

111 «Encontré aquí muy arraigada la costumbre, ..., de enterrar a los muertos con hábito de franciscanos.» (DEFOE (2002), p. 279). 
ataúd «con tapa», forrado «con bayeta negra y guarnecido con cinta blanca». Quiere que se exponga «en el portal principal de su casa con cuatro hachas del Santísimo Sacramento en los blandones de la iglesia». De su casa a la iglesia le llevarán cuatro personas pobres que le hayan servido, y se realizarán las tres posas acostumbradas.

En el segundo codicilo, del 26 de noviembre de $1752^{112}$, la preocupación de Bernabé García es que se cobren unos reales que le adeudan ${ }^{113}$. Los debe cobrar el cura de Domingo Pérez, "para el fin de que evacuase lo que a su merced tenía comunicado, sin que su yerno ni hija tuviesen intervención ni lo impidiesen en modo alguno; pues para todo da y confiere amplias facultades a dicho señor cura.» Este codicilo ya no lo puede firmar. Tres días después, el 29 de noviembre de 1752, Bernabé García muere, y es enterrado el 30 de noviembre en la iglesia parroquial de Domingo Pérez ${ }^{114}$.

\section{LA BIBLIOTECA DE BERNABÉ GARCÍA ${ }^{115}$}

En una época de España donde apenas se lee y escasamente se edita ${ }^{116}$, llama la atención que una persona que vive en un medio rural cuente con una biblioteca tan sugestiva. La sociedad rural, por lo general, era una sociedad ignorante, encerrada en su mundo y estabilizada en su atraso. En las escrituras de dotes y capitales de los campesinos, como en las de inventarios, particiones de bienes y otras escrituras, los libros brillan por su ausencia. Fuera de eclesiásticos, médicos, escribanos y otras profesiones liberales, que si cuentan con libros entre sus bienes no suelen individualizarlos, nombrarlos uno a uno

112 AHPT, protocolo 5.888.

113290 reales. Se remite al folio 147 de su libro de caja. Bernabé García ha estado repasando el libro hasta en los últimos días de su vida, a la búsqueda de un dinero que necesita para lo que tiene dispuesto y comunicado al cura.

114 La partida de defunción en APDP, Libro de difuntos VII.

$115 \mathrm{El}$ fondo de la biblioteca se puede ver en el Apéndice.

116 Véase el capítulo 7, «El ambiente intelectual en la primera mitad del siglo [XVIII]», de Domínguez (1984), 104-116. Si M. Sánchez Mariana piensa que el siglo XVIII trae más bibliotecas y que sus propietarios pertenecen a otras clases sociales que no son las habituales, R. Fernández Durán cree que en el Madrid de Felipe V y Fernando VI, salvo algunos nobles, secretarios, consejeros y profesionales liberales, eran pocos los que poseían bibliotecas (cito por ENCISO, L.M. (2002), Barroco e Ilustración en las bibliotecas privadas españolas del siglo XVIII, Madrid, Real Academia de la Historia, p. 16 y 122). En el siglo XVIII se formarían más bibliotecas que en los siglos anteriores, pero todavía eran pocas. 
como lo hace Bernabé García, los campesinos, excepcionalmente, reflejan algún Flos Santorum. En un único caso, en la dote de la hija de un rico labrador de 1700, hemos encontrado «un libro de Quevedo en prosa» y otro De la diferencia entre lo temporal y eterno de Juan Eusebio de Nieremberg ${ }^{117}$. Maxime Chevalier asegura que prácticamente todos los aldeanos están «al margen de la civilización de la escritura... Su cultura - pues no carecen de ella - es cultura fundamentalmente oral, a base de refranes, de cuentos tradicionales, de romances y canciones. No entran en el circuito del libro, no forman un público para los libreros - ni siquiera para los buhoneros. A este respecto viven lo mismo los labradores adinerados que los más humildes braceros, y muchos artesanos igual que los más pobres obreros: tendrán en sus arcas unos vestidos preciosos, unas joyas antiguas o alguna vajilla de plata, pero no compran libros» ${ }^{118}$. Otros obstáculos, además del analfabetismo y la falta de instructores, dificultan el acceso de los campesinos al libro: su deficiente circulación, el desinterés por la cultura que encierra y su precio. Los libros son caros y sólo están al alcance de personas con suficientes recursos económicos ${ }^{119}$. De aquí que se recurra al préstamo, como sabemos que Bernabé García lo practicaba con uno de sus sobrinos ${ }^{120}$.

117 AHPT, protocolo 5.787.

118 Chevalier, M. (1976), Lectura y lectores en la España de los siglos XVI y XVII, Madrid, Turner, p. 14. ENCISO, L.M. (2002). Un capítulo dedica R. Chartier a los lectores campesinos franceses del siglo XVIIII, CHARTIER, R. (1994), Libros, lecturas y lectores en la Edad Moderna, Madrid, Alianza Editorial, pp. 177-199.

119 Chevalier (1976), p. 20 y ss.

120 «Manda a Manuel Ruiz de Ahijado Bazán, su sobrino, los libros que tiene en su poder, excepto la primera parte de Mariana y la Curia Filipica» (Codicilo de Bernabé García, 16 de marzo de 1751, AHPT, protocolo 5.888). Sería interesante conocer mejor con qué intensidad se producía el intercambio de libros entre los habitantes del campo. No nos parece aventurado pensar que Bernabé García prestara sus obras de medicina al médico de la villa, como las vidas de santos o los tratados ascéticos a los clérigos que vivían en ella. De la misma forma que él recibiera préstamos de otras personas. Trevor J. Dadson asegura que el préstamo estaba muy extendido en España durante el Siglo de Oro, no sólo entre eruditos y gente poderosa, sino que entre la población más baja «se prestaba y pedía prestados libros con una frecuencia que podemos encontrar desconcertante ... « (DADSON, T.J. (1998), Libros, Lectores y Lecturas. Estudios sobre bibliotecas particulares españolas del Siglo de Oro, Madrid, Arco/Libros, p. 40). Conocemos, por ejemplo, el caso del cura de un pueblo cántabro que en el siglo XVII prestaba los libros de su biblioteca a sus fieles (M. Vaquerizo Gil, «La biblioteca de un sacerdote rural en el siglo XVII», en Altamira, I, 1975, cito por ENCISO, L.M. (2002), p. 72). R. Chartier recoge testimonios de párrocos franceses favorables a que los campesinos lean y también testimonios en contra (CHARTIER, R. (1994), pp. 177-195). 
Según el inventario de 1743, la biblioteca de Bernabé García se compone de 78 títulos y 94 volúmenes. Su valor se estima en 1.946 reales, que supone el 1'35 por ciento de todos los bienes. Los libros están escritos en castellano en el 93 por ciento, y en latín, en casi el 6'5 por ciento; hay algunas traducciones al castellano del francés y del italiano, y de algún otro libro resulta complicado conocer con certeza su lengua por la escasez de datos proporcionados. Predominan los editados en el siglo XVII (46 por ciento, aproximadamente), a continuación vendrían los del siglo XVIII (23 por ciento) y los del siglo XVI (15 por ciento); alrededor del 15 por ciento son de difícil localización.

Bernabé García continuó comprando libros después de 1743 porque en el codicilo de 1751 manda a su nieto 100 libros «firmados con su nombre», y unos cuantos más, no se precisa el número, a su sobrino. Lamentablemente desconocemos la identidad de las nuevas adquisiciones de Bernabé García; mientras con otros gastos que realizó en esos años sí dejó constancia de ellos, no fue así con los libros ${ }^{121}$.

Si nos fijamos en el contenido de los volúmenes de la biblioteca, la materia que predomina es la religiosa. Los libros religiosos fueron los más editados en España durante toda la Edad Moderna ${ }^{122}$. La biblioteca de Bernabé García reúne en torno al $42^{\prime} 3$ por ciento de libros de asuntos religiosos, si entre ellos también incluimos las Vidas de Santos y de Vírgenes y la Historia eclesiástica. Si sólo tenemos en cuenta los libros de devoción y libros pastorales, las obras apologéticas, la literatura ascética, la teología moral y dogmática, sermonarios, etc., el porcentaje baja al 26'92 por ciento.

A los religiosos le siguen los libros de Historia. Estos suponen el 29'48 por ciento si consideramos la Historia civil y la Historia eclesiástica, Hagiografías y Vidas de vírgenes. A la Historia civil pertenece el 14'1 por ciento; hemos incluido aquí un Atlas geográfico. Bernabé García contaba con alguna historia de características universales, historias de España, historias locales, etc. Poseía la Historia de España del padre Mariana, historiador revalorizado y estimado en el siglo XVIII, pero también algún que otro cronicón, textos denigrados por falsos en el mismo siglo ${ }^{123}$. Por otro lado, su amor a la patria

121 Nos referimos a 2.905 reales que ha gastado en prendas de vestir y otras partidas en los años que van de 1743 a 1751, y que incorpora a la dote de su hija (Codicilo del 16 de marzo de 1751, AHPT, protocolo 5.888).

122 Véase GARCÍA, R. (1989), Las culturas del siglo de Oro, Madrid, Historia 16; DADSON, T.J. (1998); ENCISO, L.M. (2002).

123 Por ejemplo, entre las ideas historiográficas de Gregorio Mayans y Siscar estaban las de «reprobar con desdeñoso silencio los chronicones falsos, cuyo estudio fue introducir una 
chica se aprecia en las dos partes de la Historia de Toledo del Conde de Mora y en la Historia de Toledo de Francisco de Pisa.

A continuación, con el 25'64 por ciento, vienen las obras de Literatura. La literatura barroca es la mejor representada, seguida, a la par, de la renacentista y de la dieciochesca. La literatura clásica griega (Aristóteles), la literatura clásica latina (Boecio) y los padres de la iglesia (San Agustín), están representados, respectivamente, con una obra; y en el caso de las dos primeras son exégesis de segundas personas. Junto a importantes escritores barrocos (Quevedo, Mateo Alemán, Gracián, Saavedra Fajardo ${ }^{124}$ ), encontramos destacados escritores renacentistas (Hernando del Pulgar, Santa Teresa, Diego de Estella) y del siglo XVIII (Feijoo, Torres Villarroel, Gerardo Lobo). Nos atrevemos a afirmar que el género literario preferido por Bernabé García es el poético, seguido del narrativo. En cambio, carece de obras dramáticas, a no ser que entre los seis tomos de las obras de Quevedo se incluya algún entremés, o alguna comedia en las de Gerardo Lobo; pero siempre sería teatro menor, y no piezas de los grandes dramaturgos españoles del Siglo de Oro (Lope de Vega, Calderón, Tirso) o extranjeros (Shakespeare y Molière, por ejemplo) ${ }^{125}$. También llama la atención la ausencia de obras de Cervantes, y especialmente de El Quijote.

fabulosa historia llena de prodigiosas monstruosidades y vanissimamente ensalzadora de la gloria de España» (cito por STIFFONI, G. (1985), «Intelectuales, Sociedad y Estado», Historia de España, t. XXIX, vol. II, Madrid, Espasa-Calpe, 3-148, p. 99). También Mayans consiguió que José Emanuel Miñana publicara en La Haya, en 1733, la continuación de la Historia de España de Juan de Mariana; y Feijoo tenía en alta estima la labor como historiador de Mariana (véase «Amor de la patria y pasión nacional», en Teatro crítico universal, II, Clásicos Castellanos, 1973, pp. 57 y 58).

${ }_{124}$ Al igual que Mariana, Saavedra Fajardo fue un escritor recuperado en la primera mitad del siglo XVIII. En el rescate también participaron Mayans y Feijoo. El primero escribió en 1725 Oración en alabanza de las eloquentissimas Obras de Don Diego Saavedra Fajardo y el segundo se sirve de concepciones políticas de Saavedra Fajardo para alguno de sus discursos (STIFFONI (1985), pp. 86 y 87). Comentando la Oración de Mayans, el doctor don Tomás Navarro, examinador de las facultades de filosofía y teología de la Universidad de Valencia, en carta a don Andrés de Orbe y Larreátegui del 24 de febrero de 1725, arzobispo de Valencia, expresa los juicios siguientes sobre Saavedra Fajardo: «Celébrase en esta Oración el político más elocuente que ha tenido España... Si hubo algún Alejandro en la lengua castellana, ese fue don Diego; grande en el juicio, grande en la erudición, grande y casi inimitable en el decir... Hasta hoy se tuvo don Diego por elocuente entre muchos. Hoy se empieza a venerar por uno de los clásicos maestros de la elocuencia española») (Epistolario español. Colección de cartas de españoles ilustres antiguos y modernos. Recogida y ordenada con notas y aclaraciones históricas, críticas y biográficas por D. Eugenio de Ochoa, tomo segundo, Atlas, 1965, p. 151).

125 Esta ausencia se puede explicar por el descrédito y decadencia en que cayó el teatro en la primera mitad del siglo XVIII, sin dramaturgos importantes ni obras geniales. También 
Percibimos, igualmente, un predominio de la literatura de carácter didácticomoralizante sobre la de puro entretenimiento, aunque de esto último encontramos autores festivos como Quevedo y Torres Villarroel, y textos amenos y divertidos como las Florestas de Melchor de Santa Cruz y de Francisco Asensio.

Al grupo de la Ciencia pertenece el 17'94 por ciento. Sobresalen los libros de medicina y farmacia, pero también encontramos de aritmética, astronomía o divulgación científica. Por lo que suponen para el progreso de la ciencia y de la cultura de la España de entonces, destacamos el Curso químico de Lémery y la Filosofía escéptica del doctor Martínez. Menos trascendentes son el Tyrocinio pharmacopeo de Fuente Pierola, calificado de tratado ecléctico por López Piñero ${ }^{126}$ y de galenista por Puerto Sarmiento ${ }^{127}$; y El monstruo horrible de Grecia de Bustos de Olmedilla, que, aunque criticado por los defensores de las doctrinas más tradicionales, no es considerado un novador pleno. Sin embargo, se echa en falta la obra de Félix Palacios, Palestra Pharmacéutica chímico-galénica, para Puerto Sarmiento «texto de obligatoria tenencia en las boticas españolas» ${ }^{128}$.

Plenamente preilustradas, dentro de la órbita intelectual de los novadores, son: el Curso chymico de Nicolas Lémery, la Philosophia Scéptica del doctor Martínez, el Teatro crítico universal de Feijoo y las Memorias de Trevoux.

De Política encontramos el 6'41 por ciento; de Heráldica, Nobiliaria y Genealogía, el 5'12; de Filosofía, el 3'84; Enciclopédicos, el 3'84; de Derecho, el 2'56; de Higiene Pública, 1'28; y de Cocina, 1'28 ${ }^{129}$. Sorprende que la biblioteca no contenga ningún libro de agricultura, materia que necesariamente debía interesar a Bernabé García. Quizá fueran estas obras de las más comunes en el campo, y las recibiera en préstamo.

pudo influir en Bernabé García la opinión de la iglesia, que consideraba el teatro un foco de inmoralidades y una ruina espiritual.

126 LÓPEZ, J. M (2002), «La Medicina», Historia de la ciencia y de la técnica en la Corona de Castilla. III. Siglos XVI y XVII, Salamanca, Junta de Castilla y León, p. 671.

127 Puerto (1997), p. 352.

128 PUERTO (1997), p. 458.

129 En relación con los porcentajes indicados, debemos tener presente que varias de las obras se han contabilizado en más de una materia. Por ejemplo, los libros de Santa Teresa y Diego de Estella están incluidos en los religiosos y en la literatura renacentista; las Empresas políticas de Saavedra Fajardo, en la literatura barroca y en la política; el Teatro crítico de Feijoo, en la literatura del siglo XVIII, en la divulgación científica y en los enciclopédicos, etc. Son casi siempre los libros de literatura, pero también los de divulgación científica coinciden con los de características enciclopédicas. 
Hemos comparado la biblioteca de Bernabé García con la de don Francisco Corral, su coetáneo, también boticario y toledano, aunque vivía en Madrid como ayudante del boticario mayor del rey. Establecemos las siguientes consideraciones ${ }^{130}$ :

- La biblioteca de don Francisco Corral se compone de 140 títulos y 182 volúmenes, prácticamente dobla a la de Bernabé García.

- Está muy condicionada por la profesión de su dueño. Las obras de medicina y farmacia son las más abundantes. Entre las primeras cuenta con obras de Hipócrates, D. Sennert, J. Baglivi, R. Morton, P. de Rotundis, I. Catalán, L. de Capua, G. Bustos de Olmedilla, etc. Entre las segundas posee varias Farmacopeas como la de Fuente, la Valentina, la de Palacios, la Batecina, la Triunfante, la Extemporánea, la Pharmacopea Matritensis; también el Curso chymico de N. Lémery, el Tratado de botica de L. de Oviedo, el Tyrocinium pharmaceuticum theórico práctico de J. de Loeches, el Tyrocinium chymicum e naturae de J. Beguin, libros de flebotomía, etc.

- Los libros de asunto religioso siguen en número a los de medicina y farmacia, pero no tienen el peso que en la biblioteca de Bernabé García.

- La materia histórica y literaria se encuentran en menor proporción que en la Biblioteca de Bernabé García. En cambio, hay mucha mayor presencia de literatura clásica latina.

- Contiene obras de teatro de Calderón y de Molière.

- Posee libros en lengua francesa e italiana. Destacan los franceses, donde además de obras literarias hay gramáticas, libros de viajes por Francia, etc. La influencia de la Corte de los Borbones es evidente.

- Coinciden en algunas obras (Tyrocinio pharmacopeo de Fuente Pierola, Curso Químico de Lémery, Historia de España de Mariana, El monstruo horrible de Grecia de Bustos de Olmedilla, Excelencias de la mi$s a$ ), y en algunos autores (Mesué, Gerardo Lobo, Quevedo, Gracián, Santa Teresa). Ninguno cuenta con obras de Cervantes.

- La biblioteca de don Francisco Corral no nos parece mucho más rica en contenidos y en diversidad que la de Bernabé García. Cuenta con libros

130 Debemos advertir que es un cotejo somero, orientativo, entre otras razones porque no todas las obras de la librería de don Francisco Corral se han identificado (BARRIO, J.L. (2001), «La Biblioteca de don Francisco Corral, ayuda de Boticario Mayor de Felipe V y Fernando VI (1748)», Anales Toledanos, XXXVIII, Diputación Provincial, 131-144). 
de asuntos y materias distintas que no tiene Bernabé García, como éste posee otros de los que aquél carece.

- Tampoco nos parece que sea mucho más novadora que la de Bernabé García. Sin embargo, la de Bernabé García es más representativa del modelo barroco de biblioteca (abundancia de obras religiosas, históricas, literarias, y predominio del castellano y del latín); la de don Francisco Corral está más cerca del modelo ilustrado (descenso de libros religiosos y aumento de los científicos, mayor presencia de literatura clásica griega y latina, inclusión de obras de teatro, libros de viajes, gramáticas y diccionarios, además del castellano y del latín, obras en francés, italiano, etc. $)^{131}$.

Pensamos que la biblioteca de Bernabé García es producto de sus gustos, de sus intereses, de su idiosincrasia, y por ello nos ayuda a conocer mejor a su dueño. Era una persona muy religiosa. Vivía su fe día a día como demuestran el Breviario dominicano y el Día lleno que poseía. Ferviente devoto de la Virgen, para la que mandó ejecutar el retablo mayor de la parroquia y la imagen que lo preside, y también de los santos. Debía ser un hombre de moral muy estricta, inclinado a la polémica, sin despreciar el lado placentero y divertido de la vida, el gusto por la burla y el chiste ${ }^{132}$. Su convencimiento de pertenecer al estado noble y su obsesión por demostrarlo explican los libros de genealogía. Como su profesión de boticario explica los de medicina y farmacia, y sus negocios y los cargos municipales que ocupó (como otros de mayores vuelos a los que aspiró), están detrás de las obras de derecho y política. El resto responde a su curiosidad intelectual, a sus deseos de cultura y a su afición por la lectura. La biblioteca, en suma, nos presenta una personalidad de Bernabé García tradicional, conservadora, arraigada en el siglo XVII, fundamentalmente marcada por el peso de la religión; pero también nos descubre una personalidad que se abre a las novedades intelectuales, que mira hacia el futuro. Quizá hiciera suyas estas palabras de Feijoo: «Es menester huir de dos extremos, que igualmente estorban el hallazgo de la verdad. El uno es la tenaz adherencia a las máximas antiguas; el otro la indiscreta inclinación a las doctrinas nuevas. El verdadero philósofo no debe ser parcial ni de este ni de aquel siglo. En las Naciones extranjeras pecan mucho en el segundo extremo; en España casi todos en el primero» ${ }^{133}$.

131 ENCISO, L.M. (2002), pp. 37-41.

132 Sospechamos, por algunos de los libros, ideas antisemitas y misóginas en Bernabé García.

133 Cito por STIFFONI (1985), p. 84. 


\section{CONCLUSIÓN}

La trayectoria vital de Bernabé García coincide con las distintas etapas del periodo preilustrado. Es un adolescente cuando surgen los primeros síntomas de cambio, un joven maduro cuando comienza la polémica entre novadores y tradicionalistas, un adulto cuando sale a la luz el primer tomo del Teatro crítico de Feijoo y la polémica novadores/tradicionalistas se aviva, y un anciano a punto de morir cuando el movimiento ilustrado inicia su triunfo. Bernabé García no fue ajeno a todos estos momentos. Tomó parte en ellos con la conciencia e intensidad que sus ocupaciones se lo permitían, pero su genio despierto y atento a todo lo que pasaba a su alrededor no consentía la indiferencia.

Desde muy pronto toma partido por los borbones y participa activamente en la Guerra de Sucesión. Con el rigor que le caracteriza reúne los impuestos que la monarquía necesita para la contienda y trabaja con empeño en crear las quintas y sortear los soldados que las milicias demandan ${ }^{134}$. Manifiesta ideas regalistas cuando combate en las sesiones del ayuntamiento los privilegios de los eclesiásticos y sus fraudes a la Hacienda Real. Sufre la rivalidad de presbíteros que compiten con él en los mismos negocios. A ningún vecino se le escapa que cada año ellos son más pobres, mientras los clérigos se hacen con las mejores haciendas, no pagan impuestos y disfrutan de saneadas economías; sin censos que les agobien. Esta situación crea un malestar creciente, y acaso odio, hacia unos eclesiásticos insensibles y nada solidarios. No sabemos cómo hubiese procedido Bernabé García con el otro estamento privilegiado de darse una situación similar. Pero hacía muchos años que no vivían hidalgos en la villa ${ }^{135}$ y él, por otra parte, aspiraba a pertenecer a dicho estamento ${ }^{136}$. Bernabé Gar-

134 Indica A. Domínguez Ortiz que «la masa de la población no tenía ningún deseo de participar en una guerra dinástica, pero los ministros franceses que acompañaban a don Felipe eran mucho más enérgicos que los funcionarios de Carlos II; con amenazas y promesas consiguieron movilizar aquella masa inerte. Se hizo responsables a las autoridades municipales de la movilización, prometiendo la hidalguía a los que sirvieran como oficiales; se exigieron tributos sin contemplaciones, ...» (DomínGUEZ, A. (2000), España, tres milenios de historia, Madrid, Marcial Pons, p. 205). Algún testigo de la información de 1726 relata cómo Bernabé García estaba dispuesto a alistarse en el ejército «para lograr las preeminencias que su majestad ofrecía». Quizá viera aquí otro medio para acceder a la hidalguía.

135 Había un hidalgo que sepamos, Juan de Celis y Dosal, testigo en la información de Bernabé García en 1726, que por problemas económicos no puede llevar a cabo las probanzas de hidalguía (véase su testamento, del 3 de septiembre de 1741, AHPT, protocolo 5.887).

136 Varios motivos nos llevan a pensar así: 1/ El apellido 'Cabeza de Vaca' por parte de su madre y el 'don' que aparece delante de los nombres de los abuelos maternos y de la abuela 
cía no abusó del poder como era común entre los oligarcas locales. En la información de 1726, con los reparos que se quieran alegar, es presentado como una persona íntegra, honrada, justa, eficaz, transparente, que busca el beneficio de toda la comunidad. Se propuso no perjudicar a los pobres y arreglar las disputas y disensiones que se originaban entre los ricos a la hora de repartir impuestos. Su rigor, firmeza y orden en la gestión municipal pretendía acabar con la arbitrariedad y la anarquía anterior.

Bernabé García padeció dificultades económicas, unas más apremiantes que otras, durante toda su existencia. No se vio favorecido por los momentos históricos que vivió, con guerras, aumento de tributos, etc. Dejó su profesión de boticario porque aspiraba a cotas sociales, económicas y políticas superiores. Tampoco tuvo suerte con las cosechas, y sufrió malos años que le castigaron duramente. No entendemos cómo no abandonó algunas actividades y negocios, como los arrendamientos de diezmos, que tanto le endeudaron. Por otro lado, fue un hombre generoso, desprendido, que mantuvo un nivel de vida que, en muchos momentos, no podía sostener.

Bernabé García ofrece una personalidad compleja, rica en interesantes facetas. Por su espíritu emprendedor, inquieto, sus diferentes negocios y el volumen de ellos, sus deseos de crear un capital que le permitiese vivir de forma desahogada y confortable ${ }^{137}$, etc., es casi un burgués ${ }^{138}$. No un burgués gen-

paterna, en la partida de matrimonio de sus padres. 2/ Los libros de genealogía de su biblioteca, uno de ellos referido a la casa Cabeza de Vaca. 3/ El privilegio del rey que alega para no declarar en el padrón de 1696. 4/ Su insistente ocupación en los arrendamientos de diezmos, actividad, según Domínguez Ortiz, con la que se conseguía ascender socialmente. 5/ La información de 1726, con la que quería demostrar sus méritos y virtudes personales, su vida modélica, enteramente entregada a Dios, al rey y a su comunidad (la nobleza por méritos más que por herencia se impone en el siglo XVIII). 6/ Actuaciones propias de la nobleza, como financiar obras en la iglesia y ganar sepulturas en lugares privilegiados. 7/ El asunto del 'don' en la sesión del ayuntamiento del 30 de junio de 1737 (véase también lo que decimos en la nota 134).

137 La escritura de convenio y traspaso de bienes a su hija y yerno de 1743 y el codicilo de 1751 nos ayudan a entender el nivel de vida de Bernabé García. Edificó una gran casa valorada en 43.000 reales. En ella abundaban los cuadros de tema religioso, pero también se pueden contemplar paisajes, ciudades, estampas, mapas y conclusiones. Destacaban las pinturas de un Eccehomo, en marco de talla dorado, de Antonio Palomino; y un San Ambrosio, en marco negro, del Greco. Entre las esculturas sobresalía la imagen de la Virgen de la Concepción que después donó a la iglesia, el Cristo de marfil con cruz y peana de ébano y un Niño Jesús, más modesto, con peana encarnada. Poseía objetos de plata y oro, piedras preciosas y joyas. Con respecto a los vestidos femeninos y masculinos son apropiadas estas palabras de A. Domínguez Ortiz: «las clases medias y pudientes manifestaba su poder económico y de clase a través del vestido» (DomíngueZ (1984), p. 100). En los vestidos femeninos sobresale la seda en 
tilhombre a la manera de como lo retrata Molière en su conocida comedia del mismo nombre. Con Jourdain coincide en las ganas por emparentar con la nobleza. Pero mientras el protagonista de Moliere es ignorante, ridículo, sobrado de dinero; Bernabé García es culto y con dificultades económicas.

Ya hemos indicado cómo Bernabé García está atento a las novedades intelectuales que poco a poco van introduciendo los preilustrados. Algunas obras de su biblioteca como las Memorias de Trévoux o la Filosofía escéptica del doctor Martínez respaldan lo que decimos. Pero también ciertos temas queridos por los novadores: la preocupación por lo público, el conocimiento de la historia nacional, la organización del ejército, el respeto por la justicia, etc. En los años que ocupó cargo municipal, o como repúblico, desde el ayuntamiento se tomaron iniciativas para limpiar calles, arreglar caminos, vigilar la higiene de las carnicerías, mejorar la provisión de agua potable, edificar fuentes públicas, etc.; medidas todas más racionales, propias de los nuevos aires que corren.

Pero también nos encontramos el lado tradicional de Bernabé García. Como hombre de su tiempo estuvo condicionado por el enorme peso que ejercía la iglesia en la sociedad de entonces. La materia religiosa es la predominante, y con mucha diferencia sobre las demás, en su biblioteca. Bernabé García fue un hombre de fe y de creencias sinceras, que practicaba su religiosidad día a día. También aquí se mostró una persona muy activa, haciendo todo lo que

pañuelos, cordones, puntillas, medias, cotillas, trajes y basquiñas. Abundan las últimas: basquiñas de felpa, de damasco, de teletón, de camelote; pero se dispone también de mantos, mantillas, guantes bordados, volantes de puntilla de plata, plumajes para el sombrero, adornos para el pecho, abanicos, almillas de princesa, etc. Bernabé García, además de diferentes casacas y otras prendas de vestir, contaba con espadín, bastón con puño de plata, peluca, un vestido de carro de oro con botonadura de plata y marfil, una chupa de gorgorán de Florencia y una capa de grana. Entre el vidriado y la loza hay fuentes, platos, vasos, tazas, cuencos, etc. Varios de ellos se denominan «finos» y llevan el nombre y los apellidos de su dueño. El mobiliario está compuesto de sillas, bancos, sillones, escabeles, mesas, arcas; un bufete, un escritorio y un escaparate, todo de nogal. El brasero y el calentador de bronce. Ropa para camas, mantelerías, cortinas. La cocina dispone de todo los útiles, hasta dos chocolateras de azófar y una garapiñera con su corcha. Finalmente, Bernabé García contaba con una calesa para sus desplazamientos.

138 Tenemos en cuenta las precisiones de Vicens Vives cuando sólo admite como verdaderos burgueses, en la España del siglo XVIII, a los comerciantes gaditanos y a los fabricantes catalanes; y no sin objeciones, pues eran muy conservadores en asuntos religiosos, políticos y sociales. El resto, que ni era comerciante gaditano ni fabricante catalán, formaba parte de las «clases medias influyentes» (cito por Domínguez (2000), p. 242). No obstante, también debemos considerar la Real Cédula del 13 de marzo de 1650, por la que «los farmacéuticos dejan de ser considerados miembros de los gremios artesanales menores y pasan a pertenecer a la burguesía consolidada ya durante el Barroco.» La farmacia deja de ser un Arte manual y se convierte en un Arte científica (PUERTO (1997), p. 360). 
estaba en su mano. Ejerció de mecenas artístico en la iglesia, mejoró ritos, introdujo novedades en algunas ceremonias, siempre en beneficio de la veneración del culto divino y el fomento de la devoción de los fieles. No sabemos con qué grado de escepticismo o de entusiasmo participaba en las rogativas y romerías que se aprobaban en los concejos municipales por motivo de sequías, langosta y otras calamidades. Un año antes de que saliera el primer tomo del Teatro crítico de Feijoo, asiste a lo que el escribano titula «Testimonio del prodigio de haber criado la majestad divina en un tejado un macollón de trigo, y granadole[sic] ${ }^{139}$, este año de $1725{ }^{140}$. El suceso nos recuerda a los muchos milagros y prodigios que denunció Feijoo como falsos, y que no eran sino fenómenos naturales ${ }^{141}$. La lectura de Feijoo y de otros textos similares le ayudarían a superar las supersticiones, a razonar y a pensar por sí mismo.

Por último, podríamos ver un Bernabé García con ciertas cualidades que le acercan a los proyectistas o arbitristas del siglo XVIII ${ }^{142}$. Es decir, una perso-

139 'Granó, fructificó'. El «macollón» (de Macolla, 'conjunto de vástagos, flores o espigas que nacen de un mismo pie') granó la espiga.

140 «Yo Carlos Bajo Dávalos y Cavello, escribano del Rey Nuestro Señor y del ayuntamiento y número de Domingo Pérez, doy fe que hoy nueve de agosto de 1725 pasé a las casas de Antonio López Poderoso, vecino de esta villa, con la noticia de haberse celebrado en ella el prodigio de haber criado la Majestad divina un macollón de trigo en uno de los tejados de dicha casa y granádole también como si fuera en barbecho. Y reconocí ser así, lo cual arranqué por mi mano, y estaba detenido entre un pedacillo de soga de esparto en una canal de un tejado bajo, sin más tierra por abrigo a las raíces que aquella horririlla regular que se cría de lo que causa las lluvias y polvo, sin ser ésta excesiva, pues las raíces del trigo se registraban. Y pasando a especular en mi oficio, en presencia del señor don Francisco de Haro, alcalde mayor de esta villa, del padre fray Juan de los Reyes, de la orden de Nuestro Padre San Agustín y su prior del convento de Maqueda, y de los señores Bernabé García Bermúdez y Diego Fernández Rioja y Palomo, vecinos de esta villa, las espigas que había, sus pies y el lleno del grano, resultó que en cinco pies había veintisiete espigas, unas mayores que otras, pero tan granadas como si fueran criadas en barbecho; cuya altura de dichos macollos era de tres cuartas y cuatro dedos. Y porque en los tiempos venideros conste este prodigio lo pongo por testimonio. $\mathrm{Y}$ a fin de que se oscurezca el antiguo adagio de que en las bardas se cría trigo en los años abundantes, y se diga que en años semejantes hasta en las tejas. Y finalmente para que se manifieste la gran providencia del Señor con sus criaturas. Fue asimismo presente el señor licenciado don Manuel Cano Villegas, presbítero y teniente cura de esta villa, que concurrió a la sazón; y Pedro Bazán de Agüero y Pino. Mediante lo cual doy el presente, en Domingo Pérez, dicho día nueve de agosto del año mil setecientos y veinticinco. Y lo signé y firmé.» (AMDP, Libro de acuerdos).

141 El más conocido, por los debates que desencadenó, fue el milagro de las flores de San Luis (véase ALBORG (1978), p. 160 y ss.).

142 Agustín González Enciso distingue «arbitrismo del seiscientos», que «tendía a hacer reformas dentro del sistema para que el sistema funcionara bien»; del «proyectismo del setecien- 
na preparada, con los conocimientos suficientes para responder a los problemas políticos y económicos de España. De esta forma lo describieron los testigos de la información de 1726 y ya hemos mencionado las medidas que se tomaron en el ayuntamiento promovidas por él. Claro está que no podemos comparar una villa con todo un país. No obstante, encontramos algunos puntos en común entre Bernabé García y Francisco Máximo de Moya Torres, autor del Manifiesto universal de los males envejecidos que España padece, publicado en $1730^{143}$.

Bernabé García no estuvo al margen de su tiempo, a pesar de residir en un ámbito rural, alejado de la corte y de centros urbanos. Vivió la primera mitad del siglo XVIII, cuando todavía la iniciativa de cada español prevalece sobre cualquier tutela que se imponga desde arriba. Kant definía la ilustración como la «manifestación del espíritu que osa pensar por sí mismo». La lectura le liberalizó de dependencias y de ataduras, le hizo ser un hombre independiente, libre. Aquí creo que reside el mérito de Bernabé García, en la capacidad de vivir su época con autonomía a pesar de las desventajas con las que contaba $^{144}$. Por educación y cultura, por las virtudes que aplica Fontanelle a los ilustrados ${ }^{145}$, por su concepción de la monarquía ${ }^{146}$, entre otras razones, creemos que Bernabé García hubiese sido un ilustrado convencido de haber vivido la segunda mitad del siglo.

tos», que «mira más hacia el futuro, propugna cambios en el modo de hacer las cosas, incluso en el modo de ser de las mismas». Después escribe: «Modernización, proyectismo, reformismo, coinciden en el siglo XVIII no sólo en la búsqueda de una mayor eficacia, sino en la búsqueda de lo nuevo, en el rechazo de lo antiguo, de los modos que han sido derrotados.» (GONZÁLEZ (2003), pp. 41 y 43).

143 No es que hayamos hecho un estudio pormenorizado de sus convergencias, pero los dos parece que procedían de familias hidalgas venidas a menos, los dos tuvieron problemas económicos y acudieron al rey para obtener un trabajo en la administración central, coinciden en ideas regalistas y mercantilistas, en la importancia de organizar la milicia, ....

144 En la segunda mitad del siglo triunfará el despotismo ilustrado, surgirán distintas instituciones, Sociedades Económicas, periódicos, etc., que facilitarán la tarea de los ilustrados.

145 Fortaleza, deber, resolución y valentía.

146 Pensamos que las palabras de A. Domínguez Ortiz sobre el Rey y el Estado están muy cerca de las ideas de Bernabé García: «Pero, en conjunto, hubo un claro progreso en cuanto a la identificación del interés real y el nacional, en cuanto a la aceptación del concepto del rey como primer servidor del Estado ... En este sentido fue como los hombres de la Ilustración apoyaron y justificaron el absolutismo regio; no como un despotismo egoísta, sino como la encarnación de la suprema autoridad del Estado, encarnada en el rey, que gobierna sin restricciones en nombre de todos y en beneficio de todos.» (DomíngueZ, A. (1980), Hechos y figuras del siglo XVIII español, Madrid, Siglo XXI, p. 318). 


\title{
APÉNDICE
}

\section{ANOTACIONES A LA BIBLIOTECA ${ }^{147}$}

\author{
[1].- Padre Estela, un tomo de folio --- 20 reales. ${ }^{148}$ \\ [2].-Otro tomo que se titula República cristiana ---10 r. ${ }^{149}$ \\ [3].- Una atiolo iluminado de animales, plantas y peces de folio ---- --- 120 r. $^{150}$ \\ [4].- Un Mesue antiguo --- 120 r. ${ }^{151}$
}

147 Reproducimos los títulos, autores y tasación de los libros de la biblioteca tal como aparecen en la escritura del 5 de abril de 1743 (AHPT, protocolo 5.887); la numeración de las obras es nuestra. Para la identificación de los títulos, además de obras de referencia y monografías, se ha utilizado el Catálogo Colectivo del Patrimonio Bibliográfico Español y el Catálogo Bibliográfico Ariadna de la Biblioteca Nacional, Libros Antiguos anteriores a 1831 (los dos se pueden consultar en www.bne.es). Siempre hemos preferido, cuando ello era posible, las ediciones de Madrid y Toledo (las ciudades más visitadas por Bernabé García), las ediciones del siglo XVIII, sin dejar de mencionar las primeras u otras ediciones, y las que no superaran el año 1743, año del inventario. Hemos respetado la ortografía, la puntuación y la acentuación de los títulos de las obras originales.

148 Puede que sea Diego de Estella (1524-1578), escritor ascético franciscano, predicador, consultor y teólogo de Felipe II. Escribió en latín: In Sacrosanctum Evangelium Lucae Enarratio, Alcalá de Henares, 1578; De ratione concionandi sive Reth. Ecles., Salamanca, 1576; Espicat. Psalmi CXXXVI, Colonia, 1586. Pero sus obras más conocidas son Tratado de la vanidad del mundo, 1562, y Meditaciones devotísimas del amor de Dios, Salamanca, 1576, de las que se hicieron varias ediciones y fueron traducidas a las principales lenguas europeas. No pensamos que se refiera a Miguel Estela, de la Orden de los Mínimos, sin más referencias cronológicas que la de 1702, año que publica Al Angélico Doctor Santo Tomás de Aquino ...

149 Tal vez se aluda a Juan de Santa Maria (O.F.M.), autor de Tratado de República y Política Christiana. Para Reyes y Príncipes y para los que en el gobierno tienen sus vezes, Madrid, 1615 (DADSON, T.J. (1998), p. 385). Véase nota 191.

150 Quizá se refiere a Pietro Adrea Gregorio Mattioli (1500-1577), Di Pedacio Dioscoride Anazarbeo libri cinque, Venecia, 1544 (GILlispIE, CH. (1974), Dictionary of Scientific Biography, t. IX, New York, Charles Scribner's Sons, pp. 178-180). «La edición del Dioscórides más célebre es la del médico italiano Pier Andrea Mattioli (1501-77); no es la suya la primera efectuada en Italia, pero sí la más influyente en su país y en el resto de Europa... Su extraordinario éxito se atribuye a las anotaciones y los grabados. Las dos primeras ediciones aparecieron sin dibujos, luego con unos pequeños e imperfectos y, a partir de la de Praga de 1562, con unos grabados bellos, grandes y de tendencia naturalista; además, Mattioli superó el excesivo respeto de los traductores anteriores para con el autor original y mejoró sus sucesivas ediciones mediante su propia experiencia terapéutica y herborizadora.»( PUERTO (1997), p. 273).

151 Abu Zakariya' Yuhanna ibn Masawaih (ca. 777-857), conocido en latín como Mesué senior, «es un nestoriano, hijo de un practicante de Farmacia del Hospital de Yundisapur a 
[5].- Un Mesue nuevo añadido de folio --- 90 r. ${ }^{152}$

[6].- Una farmacopea de Fuente de folio --- 16 r. ${ }^{153}$

quien en el año 806 se le encarga de la traducción de textos griegos y escritos hipocráticogalénicos. Este Mesué, de gran fama en la Europa Medieval, será traducido al latín y conocido como Mesué Ioannis Damascenni.»(MuÑOZ (1994), p. 34). Consúltese, también, HIRSCH, A. (1962), Biographisches Lexicon, t. I, Munich y Berlin, Urban \& Schwarzenberg, p. 168. Hemos interpretado el adjetivo «antiguo»(como «nuevo» en la nota siguiente) aplicado a la persona del autor; es decir, como si se tratara de distinguir un Mesué 'viejo', 'senior', de otro 'joven', 'junior'. Pero también el adjetivo «antiguo»(como después «nuevo») podría referirse a la obra 'vieja', 'estropeada', 'deteriorada', o cronológicamente anterior, de un mismo autor.

152 Se refiere a Mesué junior o Joannes Mesue, así conocido en latín, «cuyas obras sobre medicinas simples y compuestas (Canones y Antidotaria) sólo se conservan en la versión latina y desempeñaron un importante papel en la terapéutica medicamentosa (médicos y boticarios) bajomedieval.» (GARCÍA, L. (2002), «La actividad intelectual médica de las minorías judía y mudéjar», Historia de la ciencia y de la técnica en la Corona de Castilla. I. Edad Media, Salamanca, Junta de Castilla y León, p. 817.) Las obras de Mesué junior se organizan «al modo del Canon de Avicena, que constaba de un tratado de materia médica -citado habitualmente como Canones-, seguido de un antidotario más amplio que el de Nicolás, al que se añadía un libro de terapéutica con los remedios ordenados según la estructura de la patología que hizo canónica el galenismo bajomedieval: remedios para las enfermedades particulares, ordenados de la cabeza a los pies; remedios contra las afecciones de carácter universal, como las fiebres, los apostemas, los venenos; por último, las medicinas destinadas al ornato con el amplio e interesante capítulo sobre la cosmética» (GARCÍA, L. (2002), «La 'Çiençia y el ofiçio de la boticaría' ", Historia de la ciencia y de la técnica en la Corona de Castilla. I. Edad Media, Salamanca, Junta de Castilla y León, p. 888). Para Francisco Javier Puerto Sarmiento el Antidotarium sive Grabaddin medicamentorum compositum, conocido como los Cánones de Mesué, «es el texto de mayor incidencia en la farmacia renacentista e incluso barroca e ilustrada.» (PUERTO (1997), p. 164). Véase también HIRSCH (1962), t. I, pp. 173-174.

153 Es la obra de Jerónimo de la Fuente Pierola titulada Tyrocinio pharmacopeo : methodo medico y chimico en el qual se contienen los canones de Ioanes Mesue Damasceno, y su explicacion ... : ponese assimismo el Proemio de Dioscorides, traducido en castellano Tyronibus y vn antidotario medico y chimico, que comprehende todos los compuestos que oy están en vso en este Reyno de Castilla, compuesto por Geronimo de la Fuente Pierola ... boticario, y vezino de esta villa de Madrid ..., Madrid, 1683. Según José María López Piñero la obra de Fuente es un tratado farmacéutico ecléctico que, a partir de 1660, se editó en seis ocasiones (LóPEZ, J. M ${ }^{\mathrm{a}}$ (2002), «La Medicina», Historia de la ciencia y de la técnica en la Corona de Castilla. III. Siglos XVI y XVII, Salamanca, Junta de Castilla y León, p. 671). Para Francisco Javier Puerto el mérito mayor de la obra «es haberse atrevido a incluir el término Chimico en el título, pero el libro es fundamentalmente galenista... La claridad expositiva del texto, la elegancia en la relación y, seguramente, la posición institucional del boticario [fue Boticario Mayor del Hospital General y de la Pasión de Madrid y oficial de la Real Botica] hicieron que su libro fuera muy consultado y reeditado.» (PUERTO (1997), p. 352). Todas las ediciones salieron en Madrid en los años 1660, 1673, 1683, 1695, 1698 y 1721. Véase también MuÑOZ (1994), pp. 122-127. 
[7].- Primera parte de la Historia General de España del Padre Mariana, de folio --30 r. 154

[8].- Segunda parte de la Historia del Padre Mariana --- $30 \mathrm{r}$.

[9].- Impugnaciones a la Historia del Padre Mariana de Pedro Mantuano --- 15 r. ${ }^{155}$

[10].- Historia de Santo Domingo de la Calzada, de folio --- 20 r. ${ }^{156}$

[11].- Historia de Navarra de Torreblanca, de folio --- 22 r. ${ }^{157}$

[12].- Historia de Santo Domingo de Guzmán de Medrano --- 20 r. ${ }^{158}$

[13].- Historia de la Provincia de Predicadores de Medrano --- 30 r. ${ }^{159}$

[14].- Historia de Nuestra Señora de la Almudena, de folio --- 24 r. ${ }^{160}$

[15].- Historia de Nuestra Señora de Valvanera --- 10 r. ${ }^{161}$

154 La primera edición en castellano, de la primera y segunda parte de la obra, apareció en Toledo en 1601. Las ediciones se sucedieron a lo largo del siglo XVII y siglos siguientes. En el siglo XVIII se revalorizó su obra.

155 Pedro Mantuano, Advertencias a la Historia de Iuan de Mariana de la Compañia de Iesus, impressa en Toledo en latin año 1592, y en romançe el de 1601 : en que se enmienda gran parte de la Historia de España, Milán, 1611. En la segunda impresión, Madrid, 1613, se dice que «va añadida la respuesta a todas las dificultades que puso el Padre Juan de Mariana a los Discursos que prueban la venida de Santiago a España ..., y también se responde al Padre Juan de Pineda, en lo que escribió en su libro De Rebus Salomonis, de la venida de Nabucodonosor ...»

156 José González Tejada, Historia de Santo Domingo de La Calzada... y noticia de la fundacion y aumentos de la Santa Iglesia cathedral..., Madrid, 1702.

157 García de Góngora y Torreblanca, Historia apologetica, y descripción del reyno de Navarra ... : dividida en III libros con un tratado a la postre de las quatro ciencias, y artes Mathematicas ..., Pamplona, 1628.

158 Manuel José de Medrano (O.P.), Historia de la provincia de España de la orden de predicadores : primera parte contiene su ilustre origen, principios y progressos de sus fundaciones, hasta el año de MCC : tomo primero, vida de su esclarecido Patriarcha S. Domingo de Guzmán, Madrid, 1725.

159 Manuel José de Medrano (O.P.), Historia de la provincia de España, de la Orden de Predicadores : segunda parte, progressos de sus fundaciones y vidas de los illustres hijos..., contiene los... accidentes del siglo XIV de la Iglesia y II de dicha esclarecida religion... : tomo segundo..., Madrid, 1731.

160 Juan de Vera Tasis y Villarroel, Historia del origen, invencion y milagros de la sagrada imagen de nuestra señora de la Almudena : antiguedades y excelencias de Madrid..., Madrid, 1692. Otra edición: Juan de Vera Tasis y Villarroel, El Triunfo verdadero y la verdad defendida en la historia del origen, invencion y milagros de Nuestra Señora la Real del Almudena, patrona de Madrid, Salamanca, 1701. El autor nació en la década de los treinta del siglo XVII y murió en los primeros años del siglo XVIII.

161 Fray Gregorio Bravo de Sotomayor, Historia del Santuario de Valvanera, Logroño, 1610. Fray Diego de Silva y Pacheco, Historia de la Imagen Sagrada de María Santísima de Valvanera, Madrid, 1665. Más rigurosa es la obra de Benito Rubio (O.S.B.), Historia del 
[16].- Primera Parte de la Historia de Toledo del Conde de Mora ------- 30 r. ${ }^{162}$

[17].- Segunda Parte de la Historia de Toledo del Conde de Mora ------- 30 r. ${ }^{163}$

[18].- Flos Santorum de Villegas --- 45 r. ${ }^{164}$

[19].- La Práctica de Masarias --- 30 r. ${ }^{165}$

[20].- Un tomo de todas las obras de Bovadilla, de tomo muy crecido --- 90 r. ${ }^{166}$

[21].- Un tomo de la Política de Villadiego --- 30 r. ${ }^{167}$

[22].- Primera y Segunda Parte de la Curia Phelipica --- 24 r. ${ }^{168}$

venerable, y antiquissimo Santuario de Nuestra Señora de Valvanera, en la provincia de la Rioja ..., Logroño, 1761, pero cae fuera de nuestros límites cronológicos.

162 Pedro de Rojas, Conde de Mora, Historia de la imperial, nobilissima, inclita y esclarecida ciudad de Toledo... : fundacion, antiguedades, grandezas y principio de la Religion Catolica en ella y de su Santa Iglesia... vidas de sus arçobispos y Santos y Cosas memorables... ; parte primera..., Madrid, 1654.

163 Pedro de Rojas, Conde de Mora, Historia de la imperial, nobilissima, inclyta y esclarecida ciudad de Toledo... : historiase el reynado de los godos, la perdida de España, su Captividad por la entrada de los moros en ella, su govierno, vidas de nuestros... Arçobispos, santos y cosas memorables..; parte segunda..., Madrid, 1663.

164 Alonso de Villegas (1534 - ca.1615), Flos sanctorum : historia general de la vida y hechos de Jesu-Christo... y de todos los santos de que reza y haze fiesta la Iglesia Catolica... : junto con las vidas de los santos propios de España y de otros extravagantes... Cito por la edición de Madrid, 1652. La obra salió por primera vez en 1580 y se editó varias veces.

165 Alessandro Massaria (1510-1598), Practica medica, Frankfort, 1601 (August Hirsch (dir.), Biographisches Lexicon, Urban \& Schwarzenberg, Munich y Berlin, t. VI, 1962, p. 112).

166 Se debe referir a Jerónimo Castillo de Bobadilla (1547- ¿?), y a su tratado Politica para Corregidores y señores de vassallos, en tiempo de paz, y de guerra y para Perlados en lo Espiritual y Temporal entre legos, Inezes de Comission, Regidores, Abogados , y otros Oficiales publicos y de las Iurisdiciones, Preeminencias, Residencias y salarios dellos y de lo tocante a las de Ordenes y Caualleros dellas. Obra muy extensa («de tomo muy crecido», se dice en el inventario de Bernabé García), en dos volúmenes, que vio la luz en 1597, pero muy vigente y considerada en todo el siglo XVII.

167 Alonso de Villadiego Vascuñana y Montoya, Instrucción politica y práctica iudicial conforme al estilo de los consejos, audiencias y tribunales de corte y otros ordinarios del reino : utilissima para los governadores y corregidores y otros jueces ordinarios y de comission y para los abogados escrivanos procuradores y litigantes. La primera edición de que tenemos noticia es de 1612. Se publicó también en 1616, 1626, 1641, 1656, 1680, 1720, 1729, etc.

168 Juan de Hevia Bolaños (1570-1623), Primera y segunda parte de la Curia filipica: donde breve y compendiosamente se trata de los iuizios, mayormente forenses, eclesiasticos y seculares, con lo sobre ellos hasta aora dispuesto por Derecho... : y de la mercancia, y contratacion de tierra y mar... La primera parte de la Curia filipica se publicó en Lima en 1603. En España, se publicó en Valladolid en 1605, pero desconocemos si hubo otra anterior. La primera edición conjunta de la primera y segunda parte que conocemos es de 1622. Se realiza- 
[23].- Genealogía de Bonifacio Tobar --- 10 r. ${ }^{169}$

[24].- Un tomo de Reyes de Armas, su autor Guerra --- 15 r. ${ }^{170}$

[25].- Manifiesto contra la Bula de Belluga --- 5 r. ${ }^{171}$

[26].- Historia General de todos los linajes nobles de Andalucía, grabados todas las armas que pertenecen a cada linaje, de Gonzalo Argote de Molina, de folio crecido -$-150 \mathrm{r} .{ }^{172}$

[27].- Nobiliario General y Genealógico de los Reyes y Príncipes de España, Parte Primera, de folio, con las armas esculpidas de cada rey y príncipe --- 90 r. ${ }^{173}$

[28].- Segunda Parte de dicha grandeza y diferentes casas de grandes de España, del mismo folio --- 90 r. ${ }^{174}$

[29].- Obras del Padre Estela, de folio --- 22 r. ${ }^{175}$

[30].- Todas las obras en seis tomos de don Francisco Quevedo y Villegas --- 66 r. ${ }^{176}$

ron numerosas ediciones en el siglo XVII y XVIII, y su éxito llegó hasta el siglo XIX. Algún crítico duda de la autoría de Hevia Bolaños.

169 José Pellicer de Ossau Salas y Tovar (1602-1679), Genealogia de la noble y antigua casa de Cabeza de Vaca : sacada del Teatro genealogico de los Reyes, Grandes, Titulos y Señores de vasallos de España, Madrid, 1652. Escribió más obras sobre esta misma materia.

170 Suponemos que se refiere a José Alfonso Guerra y Villegas, Discurso historico politico sobre el origen y preheminencias de el oficio de heraldos, reyes de armas, feciáles y caduceadores : en que se describen algunas noticias de lo que observavan los Reyes de Armas, asi en otros Reynos Estados y Provincias como en los desta Monarquia Española ..., [¿Madrid?], 1693. Guerra y Villegas fue cronista de Carlos II y Felipe V, pero su principal ocupación fue la heráldica y la genealogía, materia en la que era toda una autoridad.

171 El cardenal Belluga (1662-1743) fue «muy conocido en su época por su destacada participación en la defensa de la causa borbónica en la región murciana [...] Pero, cuando en 1709 se produjo la ruptura del gobierno borbónico con Roma por haber reconocido al Archiduque, Belluga se puso de parte de la Santa Sede y escribió al rey un conocido Memorial. En 1719 obtuvo el capelo cardenalicio, y se trasladó a Roma en 1724, donde vivió hasta su muerte.» (DEFOE (2002), nota 50, p. 234. Véase también GonZÁLEZ (2003), pp. 82-83). Belluga deseaba efectuar la reforma de la disciplina eclesiástica, y acudió al Papa Inocencio XIII quien publicó la bula Apostolici ministerii. Los opositores a Belluga, los cabildos y los regulares principalmente, denominaron la bula como la Bula de Belluga. Al poco tiempo de ser aplicada la bula fracasó.

172 Gonzalo Argote de Molina (ca.1549-1596), Nobleza del Andaluzia, Sevilla, 1588.

173 Alonso López de Haro, Nobiliario genealogico de los reyes y titulos de España ... Madrid, 1622.

174 Alonso López de Haro, Segunda parte del Nobiliario genealogico de los reyes y titulos de España ..., Madrid, 1622.

175 Véase lo que dijimos en la nota 148.

176 Francisco de Quevedo (1580-1645) fue poeta, novelista, dramaturgo, pero además escribió en prosa obras festivas, satíricas, políticas, filosóficas, ascéticas, etc. Su poesía es de temática amorosa, burlesca, satírica, etc. Como novelista escribió Historia de la vida del Buscón, llamado don Pablos, novela picaresca. Su obra teatral es menor: loas, bailes y entremeses. 
[31].- Plaza Universal de todas las ciencias y artes --- 45 r. ${ }^{177}$

[32].- Empresas Políticas de Saavedra Fajardo --- 16 r. ${ }^{178}$

[33].- Primera Parte de El Criticón de Gracián ---15 r. ${ }^{179}$

[34].-Segunda Parte de El Criticón de Gracián ---15 r.

[35].- Tres tomos del Año Virginio --- 30 r. ${ }^{180}$

[36].- Larraga añadido - 12 r. ${ }^{181}$

[37].- Curso Químico --- 15 r. ${ }^{182}$

177 Cristóbal Suárez de Figueroa (1571-1644), Plaza universal de todas ciencias y artes, parte traducida del toscano ..., Madrid, 1615. Es una adaptación de la obra del italiano Garzoni. Se la define como obra enciclopédica «pues allí aparecen todas las curiosidades y todos los personajes más notables en ciencias y artes de la historia. Cajón de sastre útil para curiosos romanticistas» (Gullón, R. (1993), Diccionario de la Literatura Española e Hispanoamericana, 2 vols., Madrid, Alianza Editorial, p. 1.567). El autor es más conocido por El pasajero, Madrid, 1617. Refiriéndose a la Plaza universal escribe Juan Luis Alborg: «Se extiende en consideraciones sobre muchas industrias y artes, y a propósito de ellas proporciona curiosos detalles sobre formas de vida, profesiones, modas, y alude también a muchos hombres notables de las artes y la literatura.»(AlBORG, J. L. (1973), Historia de la Literatura Española. Época Barroca, Madrid, Gredos, p. 498).

178 Diego Saavedra Fajardo (1584-1648), Idea de un príncipe político cristiano representada en cien empresas, Munich, 1640. Diplomático español de amplia cultura e importante prosista barroco. Otra obra conocida suya es República literaria, publicada póstumamente en 1655. Fue un autor estimado en el siglo XVIII.

179 Baltasar Gracián (1601-1658), prosista barroco equiparable a Quevedo, escribió su obra maestra, El Criticón, en tres partes (Bernabé García poseía las dos primeras). La primera parte salió de la imprenta en 1651 con el subtítulo En la primavera de la niñez y en el estío de la juventud; la segunda, en 1653, con el subtítulo En el otoño de la varonil edad; y la tercera, en 1657, con el subtítulo En el invierno de la vejez. Escribió también: El Héroe, El político don Fernando el Católico, El Discreto, Oráculo manual y arte de prudencia, Agudeza y arte de ingenio y El Comulgatorio.

180 Suponemos que tendrá que ver con los días señalados de la Virgen en el año, sus fiestas, etc.

181 Francisco Larraga (O.P.), Promptuario de la theologia moral : muy vtil para todos los $q u[e]$ [se] han de exponer de confessores... : nueuamente reconocido, meiorado, corregido y añadido por su autor en esta vigessima quarta impression..., Madrid, 1738.

182 Nicolás Lémery, Curso chymico, Madrid, 1703. "A principios del XVIII el curso de Lémery es el punto de referencia obligado para los químicos farmacéuticos españoles, entre quienes se divulga gracias a la traducción que de él hizo Félix Palacios en 1703» (HIDALGO, E. (2002), «La química teórica y sus aplicaciones. Nuevas instituciones y nuevos saberes», Historia de la ciencia y de la técnica en la Corona de Castilla. IV. Siglo XVIII, Salamanca, Junta de Castilla y León, p. 428)». Mucho influyó Lémery (1645-1715) en la terapéutica europea. Tuvo botica en París y llegó a Boticario Real, pero por sus creencias protestantes fue perseguido hasta que abjuró de ellas. Su Cours de Chimie (París, 1675) se editó en trece oca- 
[38].- Obras de Torres --- 8 r. ${ }^{183}$

[39].- Obras de Gerardo Lobo --- 10 r. ${ }^{184}$

[40].- Historia de Toledo de Pisa --- 20 r. ${ }^{185}$

[41].- El Cronicón --- 10 r. ${ }^{186}$

[42].- Un tomo de las Cartas de Santa Teresa --- 8 r. ${ }^{187}$

[43].- Baldezebro de animales esmaltado con ellos --- 15 r. ${ }^{188}$

siones y fue traducido a las principales lenguas, «lo que le hace uno de los mayores difusores de la espagiria por Europa. El principal mérito de su texto es la claridad... Se puede considerar, sin demasiado temor a equivocarse, como un texto destinado fundamentalmente a la preparación de los medicamentos; acaso de ahí vino su extraordinaria popularidad en toda Europa.» (PUERTO (1997), p. 370). La traducción del Curso al español tuvo dos ediciones en Madrid (1703 y 1721) y dos en Zaragoza (1707 y 1710). Llama la atención que Bernabé García no cuente en su biblioteca con la obra de Félix Palacios, Palestra Pharmacéutica chímicogalénica, Madrid, 1706, según Puerto Sarmiento, «texto de obligatoria tenencia en las boticas españolas» (PUERTO (1997), p. 458). Quizá ya pensaba en vender la botica.

183 Debe ser Diego Torres Villarroel (1694-1770), prosista destacado del siglo XVIII. Comenzó escribiendo cada año, desde 1718 hasta 1767, Almanaques y Pronósticos. Quizá Bernabé García tenía la obra impresa en 1743 con el título de Sueños morales, que incluía distintas obras publicadas anteriormente por Torres como las tres partes de las Visiones $y$ visitas, La Barca de Aqueronte, El correo del otro mundo, Primero y segundo sacudimiento de mentecatos, La historia de historias y El soplo a la justicia. Su obra más conocida es Vida, ascendencia, nacimiento, crianza y aventuras del doctor D. Diego de Torres Villarroel, cuyas cuatro primeras partes se publicaron en 1742, la quinta en 1750 y la sexta en 1768 .

184 Eugenio Gerardo Lobo (1679-1750), toledano de Cuerva y de profesión militar, participó en la Guerra de Sucesión y en campañas africanas e italianas. Llegó a ser gobernador militar y civil de Barcelona. Escribió algunas comedias, y como poeta cultivó los típicos géneros de su tiempo. Hasta 1743, año del inventario de la biblioteca de Bernabé García, se publican las siguientes ediciones de sus escritos: Obras varias, Sevilla, 1713; Selva de las Musas, Cádiz, 1717; Obras poéticas, Pamplona, 1724 y 1729 ; Obras poéticas líricas, Madrid, 1738.

185 Francisco de Pisa, Descripcion de la imperial ciudad de Toledo, y historia de sus antiguedades y grandeza y cosas memorables que en ella han acontecido, de los reyes que la han señoreado, y gobernado en sucesión de tiempos, y de los Arçobispos de Toledo ... Primera parte, Toledo, 1605.

186 Tenemos localizado el Cronicón de Christian van Adrichem o Cristiano Adriconmio Delfo (1533-1585), del que se hicieron ediciones, que sepamos, antes de 1743, en 1631, 1638, 1644, 1649, 1651, 1656, 1663, 1669, 1679, 1698, 1721 y 1732. La materia del Cronicón es bíblica.

187 Santa Teresa de Jesús (1515-1582), Cartas de Santa Teresa de Iesus, madre y fundadora de la Reforma de la Orden de N. Señora del Carmen... / Con notas del... Iuan de Palafox y Mendoza, Obispo de Osma... ; recogidas por orden de el Reverendissimo Padre Fray Diego de la Presentación... ; tomo primero... Hay varias ediciones de las Cartas de Santa Teresa y en distintos tomos y partes. Esta que reproducimos es de Madrid, 1678. 
[44].- Armas contra la Fortuna --- 10 r. ${ }^{189}$

[45].- Cataluña desengañada --- 10 r. ${ }^{190}$

[46].- República cristiana y razón de Estado --- 10 r. ${ }^{191}$

[47].- Engaños de mujeres contra los hombres ---10 r. ${ }^{192}$

[48].- Libros elocuentes --- 10 r. ${ }^{193}$

[49].- El gobernador instruido --- 8 r. ${ }^{194}$

[50].- Filosofía escéptica de Martínez --- 10 r. ${ }^{195}$

188 Andrés Ferrer de Valdecebro (1620-1680), Govierno general, moral y politico, hallado en las fieras y animales sylvestres : sacado de sus naturales virtudes y propiedades : con particular tabla para sermones varios de tiempo y de Santos; cito por la edición de Madrid de 1680. Valdecebro, religioso dominico, fue profesor de Teología moral y predicador grandilocuente. Tomás de Iriarte critica esta obra de Valdecebro en su fábula «El mono y el titeretero», y le acusa de confuso y nada claro (T. de Iriarte, Poesías, Espasa-Calpe, 1976, pp. 12-14).

189 Antonio Perez Ramírez, Armas contra la fortuna, fabula temida de los hombres : maximas politicas y morales sobre Boethio De Consolatione Philosophica...: repartido en metro y prosa, sirviendo de norte Boethio a quien traducido se aplican varias digresiones, Valladolid, 1698.

190 Alejandro de Ros, Cataluña desengañada : discursos políticos, Nápoles, 1646.

191 Juan Remírez de Arellano, Republica christiana y destierro de los vicios : razon de estado y politica de la virtud [de] la eterna salvación, Madrid, 1662.

192 Miguel de Montreal, Engaños de mujeres y desengaños de los hombres : divididos en cuatro discursos...; al fin va añadida la novela de los tres maridos burlados, Madrid, 1709.

193 Puede referirse a Varios eloquentes libros, recogidos en uno : escrivieronlos diferentes autores, Madrid, 1729, cuyo compilador es Juan Bautista Aguilar. Contiene : Retrato político del Rey Don Alfonso el VIII de Gaspar Mercader y de Cervellón; El perfecto privado de Pedro Fernández Navarrete; Advertencias politicas y morales de Félix de Lucio Espinosa y Malo; Gobierno moral á Lelio de Jacinto Polo de Medina; Gobierno moral á Fabio de José Prudencio Rubio y Bazán; Gobierno Moral á Lauro de Juan Bautista Aguilar; Heraclito defendido: filósofo que lloraba siempre los sucesos del mundo de Antonio de Vieyra.

194 Debe corresponder a Giuseppe Mannia, El Gouernador prudente y juez instruido : documentos generales y particulares, Madrid, 1730.

195 Es la obra de Martín Martínez Philosophía Scéptica, extracto de la physica, Madrid, 1730. En ella se «plantea un diálogo entre un aristotélico, un cartesiano, un gassendiano y un escéptico que es él mismo [Martín Martínez]. Todos ellos representantes de las corrientes filosóficas características de la época, entre las que no contaba la forma newtoniana de entender la naturaleza.» (Moreno, A. (2002), «La Física Moderna», Historia de la ciencia y de la técnica en la Corona de Castilla. IV. Siglo XVIII, Salamanca, Junta de Castilla y León, p. 358). El doctor Martínez (1684-1734), fue médico de cámara de Felipe V, examinador del Real Protomedicato y titular de la cátedra de anatomía del Hospital General de Madrid entre 1707 y 1734. Otras obras suyas son: Noches anatómicas (1716) y Medicina scéptica y cirugía moderna, con tratado de operaciones quirúrgicas (publicada en dos tomos los años 1722 y 1725 , respectivamente). Con la última de las obras provocó una sonora polémica, en la que 
[51].- Vida de San Francisco Solano --- 10 r. ${ }^{196}$

[52].- Diferencia entre lo temporal y lo eterno ---10 r. ${ }^{197}$

[53].- Obras del Príncipe Esquilache --- 10 r. ${ }^{198}$

[54].- Filosofía Moral --- 12 r. ${ }^{199}$

[55].- Tablas Cronológicas --- 8 r. ${ }^{200}$

[56].- El Guzmán de Alfarache --- 10 r. ${ }^{201}$

intervino Feijoo defendiendo al autor: «Los novadores se apuntaron un éxito por aquellos años con la publicación de la Medicina scéptica, del doctor Martínez, que había de motivar la aparición pública del padre Feijoo.» (PALACIO, V. (1985), «Prólogo», Historia de España, t. XXIX, v. I, Madrid, Espasa-Calpe, IX-LXXII, p. LVIII). Sus escritos anatómicos han sido muy valorados, y tenidos entre los más valiosos de su tiempo. Para Gregorio Marañón el doctor Martínez fue el precursor de la reforma de la enseñanza y del pensamiento médico.

196 Diego de Córdoba y Salinas (O.F.M.), Vida, virtudes y milagros del Apostol del Peru el Venerable P.e Fray Francisco Solano de la Serafica Orden de los Menores de la Regular Obseruancia, patron de la ciudad de Lima ... : sacada de las declaraciones de quinientos testigos ... y de otras muchas informaciones ..., Madrid, 1643. Puede que Bernabé García tuviera la obra de Juan Rodriguez de Cisneros (O.F.M.), Epitome de la vida, virtudes, y milagros del portentoso apostol del reyno del Peru, S. Francisco Solano ..., Madrid, 1727.

197 Juan Eusebio de Nieremberg (S.I.), De la diferencia entre lo temporal, y eterno : crisol de desengaños, con la memoria de la eternidad, postrimerias humanas y principales misterios divinos, Valencia, 1685. Existen varias ediciones de esta obra en el siglo XVIII.

198 Francisco de Borja, Príncipe de Esquilache (1582-1658), Las obras en verso de Don Francisco de Borja Principe de Esquilache .... Madrid, 1648. Hay una edición de los Versos divinos y humanos del Príncipe de Esquilache, sin fecha ni lugar de edición, posiblemente impresa en el siglo XVIII.

199 Suponemos que se refiere a Emmanuele Tesauro (1591-1675), Filosofia Moral derivada de la alta fuente del grande Aristoteles Stagitita, Madrid, 1733. Podría tratarse de Juan de Torres, Philosophia moral de príncipes, Burgos, 1596.

200 Las posibilidades aquí pueden ser varias, aunque el asunto de la obra sea el mismo. Se puede referir a Claude Clément (1594-1642), Tablas chronologicas, y breve compendio de las historias mas notables de España, politicas y eclesiasticas, desde su fundacion hasta el año de 1545, Madrid, 1645. Del mismo autor: Tablas chronologicas en que se contienen los sucessos eclesiasticos y seculares de España, Africa, Indias Orientales y Occidentales : desde su principio hasta el año $1642 . .$. : con los catalogos de los pontifices, emperadores..., varones ilustres en Letras y Armas.. : ilustradas y añadidas desde el año 1642 hasta el presente de 1689 ... por Vicente Ioseph Miguel ..., Valencia, 1689. Puede ser Luis López, Tablas chronologicas, uniuersales de España : desde el año mil y ochocientos, de la creacion del mundo, en que la començó a poblar el Patriarca Tubal, hasta nuestros tiempos, por 3799 años..., Zaragoza, 1637. José Antonio Garcilaso, Tablas historio-graphicas y cronologicas sacro-prophanas de los papas, cismas ... desde el nacimiento de ... Iesu. Christo hasta el año presente, Madrid, 1742. Etc.

201 Mateo Alemán (1547-1615), Primera Parte de Guzmán de Alfarache, Madrid, 1599. La Segunda Parte de la vida de Guzmán de Alfarache, atalaya de la vida humana, se publicó 
[57].- Grandeza y Santidad de los sacerdotes y excelencia de la misa --- 10 r. $^{202}$ [58].- Un tomo de varios sermones --- 8 r. ${ }^{203}$

[59].- Catecismo Romano del Padre Eusebio --- 10 r. ${ }^{204}$

[60].- Vida de Santa Bárbara --- 4 r. ${ }^{205}$

[61].- Avisos para la muerte --- 5 r. ${ }^{206}$

[62].- Vallester contra Fray Job --- 15 r. ${ }^{207}$

[63].- Arte de cocina --- 6 r. ${ }^{208}$

en Lisboa, en 1604. Es la obra maestra de la novela picaresca, la «más representativa ..., su cima y plenitud» (ALBORG (1973), p. 469). Su éxito fue grande desde muy temprano, y como le ocurriera a Cervantes con Alonso Fernández de Avellaneda y El Quijote, Mateo Luján se adelantó a Alemán y en 1602 publicó su Segunda parte de la vida del pícaro. La novela de Mateo Alemán se tradujo al francés, al alemán, al inglés, al holandés, etc.

${ }^{202}$ Lo más parecido que hemos encontrado es Fray Diego de Guzmán (O.SS.T.), Tratado de la excelencia del Sacrificio de la Ley Evangelica con un arte de oir la misa con devoción, Valladolid, 1599.

203 Puede ser Pedro Moreno (O.F.M.), Sermones varios ; con el Elenco para las dominicas de Adviento y Quaresma y para las Ferias principales della y un Indice de lugares de la Sagrada Escritura ; tomo segundo ..., Madrid, 1674.

204 Juan Eusebio Nieremberg (1595-1658), Practica del catecismo romano y doctrina christiana : sacada... de los catecismos de Pio V y Clemente VIII... : con las divisiones y adiciones necessarias al cumplimiento de las obligaciones christianas... : van al fin añadidos varios exemplos de los puntos principales de la doctrina... , Madrid, 1646. Hay ediciones del siglo XVIII.

205 Gregorio Candel (O.C.), Siete portentosos milagros de la insigne Virgen, y Martir Santa Barbara, que prometen a sus devotos, la gracia de no morir sin los sacramentos, y de asistirles en el peligroso transito de la muerte ... : [siguese vn epitome de su vida ...], Valencia, 1667. Fray Francisco de Jesus María (O. de M.), Arco de paz y torre de fortaleza, vida, martyrio y milagros prodigiosos de Santa Barbara Virgen y martyr ..., Madrid, 1695. Fray Jaime Ferrer (O.F.M.), Historica, y predicable trialpha de la gloriosa Santa Barbara : esto es, historia ... de la ... Vida, martyrio, muerte ... y milagros de ... Santa Barbara / con un Tratado ternario, ú tripartito ..., Barcelona, 1703.

206 Luis Ramírez de Arellano, Avisos para la muerte / escritos por algunos ingenios de España ...; recogidos y publicados por Don Luis Remirez de Arrellano, Madrid, 1634. Se trata de poesía religiosa.

207 No hemos localizado ningún escrito que se aproxime a los datos que proporciona la biblioteca de Bernabé García. Con el apellido Ballester hay varios religiosos y teólogos españoles de los siglos XVI y XVII que pudieran haber escrito esta obra: 1/ Juan de la Madre de Dios Ballester (1540-1606), carmelita descalzo, teólogo y predicador. 2/ Luis Ballester (1544-1624), teólogo jesuita. 3/ Francisco Ballester (1609-1660), religioso mercenario, de reconocido ingenio y notable erudición. 4/ José Ballester (1610-1668), teólogo agustino, muy estimado como orador sagrado. 5/ Juan Bautista Ballester (1624-1670), teólogo precoz y escritor fecundo. Etc.

208 Escribe Sagrario Muñoz Calvo que a «lo largo de los siglos XVI y XVII ciertos españoles se preocupan y muestran un interés acusado por cuestiones alimenticias; desde los crea- 
[64].- Casani de cometas --- 4 r. ${ }^{209}$

[65].- Vidas de varios monarcas --- 4 r. ${ }^{210}$

[66].- Teatro crítico --- 4 r. ${ }^{211}$

[67].- Claros varones de España ---4 r. ${ }^{212}$

[68].- Centinela de judios --- 6 r. ${ }^{213}$

[69].- Día lleno --- 6 r. ${ }^{214}$

[70].- El Monstruo de Grecia --- 6 r. ${ }^{215}$

dores de la picaresca, hasta los más eruditos doctores insertan en sus obras descripciones o comentarios bromatológicos que en el último caso, al tratarse de profesionales de la medicina, se convierten en auténticos textos de nutrición. [...] libros sobre alimentos y cómo alimentarse, mitad científicos, mitad recetarios de cocina, van a aparecer ... firmados por prestigiosos nombres de la medicina.»(MUÑOZ (1994), pp. 151 y 152). En el inventario de Isabel Montero (1629) se recoge un «Arte de cocina en tres reales». En nota, entre otras referencias, se cita a Fco. Martínez Motiño, Arte de cozina, pastelería, bizcochería y conservería, Madrid, 1611 (véase DADSON (1998), p. 461).

209 José Cassani (S.I.) (1673-1750), Tratado de la naturaleza, origen, y causas de los Cometas, con la historia de todos los que se tienen noticia haberse visto... y con el methodo de observar Astronomicamente sus lugares aparentes..., Madrid, [1737?].

210 Puede referirse a distintas obras de temática similar, como, por ejemplo, Francisco Xavier Manuel de la Huerta y Vega, España primitiva : historia de sus Reyes y monarcas desde su poblacion hasta Christo, tomo primero, Madrid, 1737 (el tomo segundo se publicó en 1740).

211 Benito Jerónimo Feijoo (1676-1764), Teatro crítico universal. El primer volumen sale en Madrid en 1726, y lleva como subtítulo Discursos varios en todo género de materias para desengaño de errores comunes. La obra consta de ocho volúmenes que se publican entre 1726 y 1739. Los ocho volúmenes reúnen 118 discursos sobre temas varios: artes, astronomía, geografía, economía, derecho político, filosofía, metafísica, física, matemáticas, historia natural, literatura, medicina, historia, supersticiones, etc. Obtuvo un éxito rotundo, agotándose sus ediciones rápidamente. Otra obra importante de Feijoo, que también disfrutó de gran éxito, fueron las Cartas eruditas y curiosas, en cinco volúmenes, que vieron la luz entre 1741 y 1760. Feijoo es una referencia cultural de primer orden en la España del siglo XVIII, especialmente en su primera mitad.

212 La obra más conocida es la de Hernando del Pulgar, Claros varones de Castilla, cuya primera edición es de Toledo, 1486. Existen ediciones de los siglos XVI, XVII y XVIII (la primera edición del siglo XVIII, que sepamos, es de 1747). Pero quizá se trate de Juan Benito Guardiola, Tratado de nobleza, y de los titulos y ditados que oy dia tienen los varones claros y grandes de España, Madrid, 1591.

213 Francisco de Torrejoncillo (O.F.M.), Centinela contra iudios : puesta en la torre de la Iglesia de Dios, Madrid, 1676. Hay ediciones de 1720, 1723, 1728 y 1736.

214 Francisco Garcia (1641-1685), Día lleno : exercicios devotos para gastar el día en servicio de Dios, Madrid, 1682. Jesuita que se dedicó durante muchos años a las misiones. Su producción literaria es abundante. 
[71].- Aritmética de Moya --- 8 r. ${ }^{216}$

[72].- Jacobo Silbio --- 8 r. ${ }^{217}$

[73].- Vida, virtudes y reflexiones de San Pedro Alcántara --- 6 r. ${ }^{218}$

[74].- Confesiones de San Agustín --- 4 r. ${ }^{219}$

[75].- Devoción de San José --- 4 r. ${ }^{220}$

215 Gonzalo Bustos de Olmedilla, El monstruo horrible de Grecia, mortal enemigo del hombre, Valencia, 1669. José María López Piñero presenta a Gonzalo Bustos de Olmedilla como un médico que critica «algunos aspectos de las doctrinas tradicionales desde posturas asistemáticas de base empírica». Recibe ataques de los partidarios de las doctrinas tradicionales, aunque no sea un novador «en sentido estricto» como Juan de Cabriada. Para López Piñero Gonzalo Bustos de Olmedilla y Juan Nieto Valcárcel son «críticos asistemáticos» (LÓPEZ (2002), p. 675). Bustos de Olmedilla contribuye con su obra a terminar con la polémica que durante el siglo XVII se desencadena en torno a la sangría, en cuanto «combate el abuso de esta práctica galenista y se opone a los excesos cometidos con la sangría, desde su propia experiencia clínica.»(PUERTO (1997), p. 325).

216 Juan Pérez de Moya, Aritmética práctica y speculativa, Salamanca, 1562. Fue de los manuales de esta materia más editados en España durante los siglos XVI y XVII. Bachiller y canónigo formado en las universidades de Salamanca y Alcalá, fue capellán del conde de Benavides, su mecenas. Es también autor de un Tratado de matemáticas, el más importante del siglo XVI, una Geographía y un Arte de navegar (ESTEBAN, M. y SALAVERT, V. (2002), «Las Matemáticas», Historia de la ciencia y de la técnica en la Corona de Castilla. III. Siglos XVI y XVII, Salamanca, Junta de Castilla y León, 231-257).

217 Se trata de Jacques Dubois (1478-1555), cuyo nombre latino era Jacobus Sylvius, galenista que fue profesor en París y crítico con la nueva anatomía establecida por Vesalio. Algunas de sus obras: Methodus medicamenta componendi : ex simplicibus, iudicio summo delectis et arte certa paratis.: quatuor libris distributa, París, 1541; De medicamentorum, simplicium preparatione, París, 1542; In Hippocratis elementa Iacobi Syluii medici commentarius, Venecia, 1543; Ratio medendi morbis internis prop ${ }^{-}$omnibus, Medicinae candidatis nou exiguae commoditati futura, $\grave{e}$ Galeni scriptis \& Marci Galtinarie (vt vocât) practica, Lyon, 1549; Iacobi Sylvii ... Opera medica : iam demum in sex partes digesta, castigata et indicibus necessariis instructa, Ginebra, 1635. Es autor también de un comentario a Mesué (HIRSCH (1962), t. II, pp. 315-316).

218 Juan de Santa María (O.F.M.) (1551-1622), Vida, excelentes virtudes y obras miraculosas del santo Fray Pedro de Alcantara, fundador de la prouincia de San Ioseph de los Descalços de la Orden de ... San Francisco en España, Madrid, 1619. Damián de Jesús (O.F.M.), Compendio de la vida y milagros de el glorioso San Pedro de Alcantara ... : con el Tratado de Oracion y Meditacion que escriuio el Santo .... Madrid, [1655]. Juan de San Bernardo (O.F.M.), [Chronica de la vida... del... glorioso y santo padre Pedro de Alcantara... fundador de la Descalcez de nuestro serafico padre San Francisco], [¿Nápoles, 1677?].

219 Existen varias ediciones, reproducimos ésta de San Agustín, Obispo de Hipona (354430), Las Confesiones, Salamanca, 1569.

220 Ramón de San José (O.C.D.), Despertador christiano a la devocion de San Joseph ... : Tomo primero, Barcelona, 1745. Salvo esta edición, que por el año tampoco podía ser la de Bernabé García, todas las ediciones que conozco son del siglo XIX, como, por ejemplo, ésta 
[76].- Floresta española --- 4 r. ${ }^{221}$

[77].- Segunda Parte de dicha Floresta --- 4 r. ${ }^{222}$

[78].- Erección de jardines y limpieza de Madrid --- 4 r. ${ }^{223}$

[79].- Cinco tomos de las memorias de Trebeus de Francia por las ciencias de París -$-25 r^{224}$

de José Antonio Patrignani (S.I.) (1659-1733), La devoción a San José : establecida por los hechos, Barcelona, 1862. Francisco García, autor del Día lleno (véase nota 214), es autor de Gloria y excelencias de San José.

221 Melchor de Santa Cruz Dueñas, Floresta española de apotegmas o sentencias, sabias y graciosamente dichas, de algunos españoles, Toledo, 1574. Obtuvo un considerable éxito editorial y se tradujo al francés, inglés, italiano y alemán. A pesar de que fue condenada en 1710 por los censores, hay ediciones, en Madrid, de 1716 y dos de 1728; una de las de 1728 con ampliaciones de Francisco Asensio (CABAÑAS, M. (1996), «Introducción» y «Apéndices», Floresta española, Madrid, Cátedra, 11-86 y 583-611, respectivamente.

222 Debe ser la Segunda Parte de Francisco Asensio, Madrid, 1728. En 1731 salió una Tercera Parte del mismo autor.

223 Pensamos que puede referirse a una de estas obras: Andrés Martí, Proyecto que D. Andres Marti ... pone a los ... pies de Vuestra Magestad, Sobre la limpieza de las calles de Madrid, construcciones de Jardines, Huertas, y Arbolados en sus cercanias, y considerables utilidades que de todo resultan à favor de la Real hacienda de V. Mag. Villa, y Corte, Arzobispado de Toledo, bien comun, y particular; y se satisface à algunos reparos puestos à este Proyecto ..., Madrid, 1738; o Vicente Alonso Torralva, Empeño español que hace patente el modo de limpiar las calles de Madrid con modo no practicado en España : propone algunos reparos acerca de la limpieza, à el proyecto de D. Andrés Martí, y hace patente el modo practico de la condución del Rio Xarama / escrito por D. Vicente Alonso Torralva ..., Madrid, 1738.

224 Trévoux es un municipio francés que en 1603 creó su famosa imprenta y en 1707 la Academia de Trévoux. De la imprenta surgieron, a partir de 1701, el Journal de Trévoux, dirigido por los jesuitas, y el Dictionnaire. El Journal tenía por objeto informar a Europa de los avances que se producían en las Artes y en las Ciencias. En España, asegura J. L. Alborg, las «clases educadas, al no poder hallar en su país los libros que exigían su afán de ilustración, acudían cada vez más a las publicaciones extranjeras, particularmente a las francesas, que les ponían en contacto con todo el movimiento intelectual de Europa.» (AlBORG (1978), p. 54). Por otro lado, A. Domínguez Ortiz escribe: «En el discurso [de Feijoo] titulado 'Nueva precaución contra los artificios de los alquimistas' dice que podría haber en España diez personas que tuviesen las Memorias de Trévoux, pero que no cree las hubiesen leído más de tres o cuatro» (DomíngUEZ (1980), p. 206).

El Diario de los literatos de España (1737-1742), quizá la publicación periódica más importante del siglo XVIII, confiesa, en la Introducción al tomo I, tener como modelo las Memorias de Trévoux, «que comenzaron con el siglo presente, empleándose en ellas con manifiestas ventajas a todos los demás Journalistas, los Padres de la Compañía de Jesús, como se demuestra en lo selecto de las Obras que extractan, en la exactitud y extensión de los Extractos, en la equidad con que critican los Libros, y en el urbano artificio con que dan a conocer los defectos 
[80].- Atlas abreviado de todo el mundo, con estampas de todo él impresas --- 66 r. ${ }^{225}$ [81].- Cronología de los Pontífices y Reyes del mundo --- 33 r. ${ }^{226}$

[82].- Un breviario Dominicano --- 33 r. ${ }^{227}$

[83].- Primera Parte de la Vida de Ripalda --- 4 r. ${ }^{228}$

de algunos Escritores; circunstancias que no se hallan juntas en ninguna otra compañía de Jornalistas» (ALBORG (1978), n. 87, p. 53).

En 1742, don José de la Torre inicia la traducción al castellano de las Memorias de Trévoux bajo el título Memorias para la Historia de las Ciencias y Artes, que se empezaron a imprimir en el año 1701 en Trévoux. En 1752, las traducciones las continúa don José Vicente Rustant, y en 1755, Antonio Ruizdiaz.

Todavía Francisco Mariano Nipho, en 1763, con el Diario Estrangero, publicación semanal que duró 22 números, tenía entre sus modelos a las Memorias de Trévoux (además de la obra citada de Alborg, ENCISO, L. M. (1985), «Prensa y Opinión pública», Historia de Espa$\tilde{n} a$, t. XXIX, v. II, Madrid, Espasa-Calpe, 195-310).

225 Hay ediciones de finales del siglo XVII y del siglo XVIII, casi siempre en ciudades extranjeras. Indico ésta de Madrid de 1709: Francisco de Aefferden (1653-1709), El atlas abreviado o compendiosa geografia del mundo nuevo antiguo y nuevo... : ilustrada con quarenta y quatro mapas... Hay otro atlas de Ginés Campillo, pero ya de 1746, Compendio curioso del atlas abreviado : el que con mucha claridad da noticia de todo el Mundo, y curas inventadas, Sevilla.

226 Aunque el título no ofrece dudas del contenido de la obra, no hemos encontrado ninguna que reúna la historia de los papas y de los reyes. Véase nota 200.

${ }^{227}$ Los breviarios son libros que recogen los rezos eclesiásticos de todo el año. El común a todas las iglesias de occidente es el Breviario Romano. El Breviario Dominicano fue redactado por Humberto, general de la orden de París, en 1253. Se diferencia del Romano en algunas particularidades de las iglesias de París del siglo XIII, en la inclusión de todos los santos de la orden de Santo Domingo, en que la Salve Regina es la antífona final en la lectura del Martirologio, etc.

228 No hemos localizado una obra con tal título. Puede referirse a Jerónimo Martínez de Ripalda (1536-1618), escritor y religioso jesuita. Nace en Teruel y muere en Toledo. Ingresa en la Compañía de Jesús en 1551. Fue maestro de humanidades, filosofía y teología, y rector del Colegio de Salamanca. Se distinguió como orador sagrado. Su principal obra es el Catecismo y exposición breve de la doctrina cristiana, Toledo, 1618, cuyas ediciones se han sucedido a lo largo de los siglos y ha estado en uso en las escuelas hasta el siglo XX. Es autor también de Suave coloquio del pecador con Dios, la Versión del latín al español del libro de Contemptus Mundi, de Kempis, y de libros panegíricos y de exhortaciones espirituales.

Menos probable, creemos, es que se trate de Juan Martínez de Ripalda (1594-1648), teólogo nacido en Pamplona y muerto en Madrid. En 1609 entra en la Compañía de Jesús. Fue catedrático de teología escolástica en Salamanca y de moral en Madrid, y en ambas materias se le reconocieron sus méritos. Sus opiniones se calificaron a veces de ingeniosas y audaces. Disputationes theologicae de ente supernaturale, Burdeos, 1634, pasa por ser su principal obra. También escribió Expositio brevis litterae Magistri sententiarum, Salamanca, 1635, y Tractatus theologici et scholastici de virtutibus Fide, Spe et Charitate, Lyon, 1652. 


\section{LIBROS DEL PADRE 229}

\section{— LIBROS QUE HEREDA BERNABÉ GARCÍA:}

- Un libro grande titulado Guido, 20 r. ${ }^{230}$

- Otro libro grande titulado Anatomía, 18 r.

- Otro libro grande titulado Fabricio, 24 r. ${ }^{231}$

- Dos libros pequeños, $6 \mathrm{r}$.

- La mitad de 107 libros de diferentes tratados, que se aprecian a 4r. cada uno, $214 r^{232}$

\section{— LIBROS QUE HEREDA DOÑA MARÍA GARCÍA:}

- Un libro de cirugía titulado Dionisio Daza, 33 r. ${ }^{233}$

229 El padre fue cirujano durante varios años de Domingo Pérez. Los libros los heredan Bernabé García y su hermana doña María García, monja en el convento de Santa Catalina la Real del Belmonte; pero la hermana se los dona. Bernabé García debió venderlos porque, al menos, ninguno de los identificados se encuentra en el inventario de 1743.

${ }^{230}$ Guy de Chauliac (1300-1368), Inventarium sive Chirurgia Magna, 1368. Este tratado quirúrgico, conocido entre los renacentistas por Chirurgia Magna, se convirtió en el «texto sobre el que giró la formación de los cirujanos desde finales del siglo XIV» (AMASUNO, M. y GARCÍA, L. (2002), «El control social de la práctica médica», Historia de la ciencia y de la técnica en la Corona de Castilla. I. Edad Media, Salamanca, Junta de Castilla y León, 827861, p. 845). Para las traducciones y ediciones de la Chirurgia Magna véase ARRIZABALAGA, J. (2002), «El libro científico en la primera imprenta castellana (1485-1520)», Historia de la ciencia y de la técnica en la Corona de Castilla. II. Edad Media, Salamanca, Junta de Castilla y León, 619-649, p. 640. Quizá la edición que poseía el padre era La magna y canonica cirugia de Guido de Cauliaco ... ; con la glossa del doctor Falcon ; y lo que a su modo dispuso el doctor Caluo ... ; añadida su Cirujia parua ò Recetario, nueuamente traduzida, con las notas necessarias de su inteligencia, por ... D. Fernando Infante de Aurioles ... ; sale ... en esta impression el Tratado de las Flores de Guido, Aphorismos ò gnomologias sacadas de sus doctrinas, Madrid, 1658.

231 Girolamo Fabrici, Crisol de la cirugía, Madrid, 1676.

232 Refiriéndose a los defectos de los inventarios de bibliotecas particulares, Máxime Chevalier sitúa en primer lugar «la falta de precisión de buena cantidad de los inventarios que han llegado hasta nosotros. Lo que les interesaba a los notarios y albaceas era, lógicamente, el valor material del conjunto que se les ofrecía más bien que la cultura del difunto. Por eso apuntaron frecuentemente con lamentable rapidez el contenido de las bibliotecas que examinaron.» (Chevalier (1976), p. 41). Más testimonios en EnCISO, L.M. (2002), pp. 17-21.

233 Dionisio Daza Chacón publicó su primera parte de Pratica y Theórica de cirugía, en Valladolid, en 1582. La segunda parte también salió en Valladolid, 1595, al igual que las dos partes conjuntas, en 1609. 
- Otro libro titulado El Maestro Lugdonense, 20 r. ${ }^{234}$

- Otro libro grande titulado Anatomías de Valverde, 20 r. ${ }^{235}$

- La mitad de 107 libros, grandes y pequeños, de medicina y cirugía latinos, en 4 r. cada uno, 214 r.

\section{BIBLIOGRAFÍA Y FUENTES DOCUMENTALES.}

\section{BIBLIOGRAFÍA.}

AlBorg, J.L., Historia de la Literatura Española. Época Barroca, Gredos, Madrid, 1973.

Alborg, J.L., Historia de la literatura española. Siglo XVIII, Gredos, Madrid, 1978.

AMASUNO M. y GARCÍA BALLESTER, L., «El control social de la práctica médica», en Luis García Ballester (dir.), Historia de la ciencia y de la técnica en la Corona de Castilla. I. Edad Media, Junta de Castilla y León, Salamanca, 2002, pp. 827-861.

ANES, G., «De diezmos y tazmías» y «Las subastas de los diezmos y otras rentas en la España de finales del Antiguo Régimen», en Cultivos, cosechas y pastoreo en la España Moderna, Real Academia de la Historia, Madrid, 1999, pp. 165-200 y 201-240, respectivamente.

ARRIZABalagA, J., «El libro científico en la primera imprenta castellana (14851520)», en Luis García Ballester (dir.), Historia de la ciencia y de la técnica en la Corona de Castilla. II. Edad Media, Junta de Castilla y León, Salamanca, 2002, pp. 619-649.

BARRIO MoYA, J.L., «La Biblioteca de don Francisco Corral, ayuda de Boticario Mayor de Felipe V y Fernando VI (1748)», en Anales Toledanos, XXXVIII, Diputación Provincial, Toledo, 2001, pp. 131-144.

CABAÑAS, M., «Introducción» y «Apéndices»a Melchor de Santa Cruz, Floresta española, Cátedra (Colección Letras Hispánicas, 411), Madrid, 1996.

CAÑIZAReS, J., El picarillo en España, señor de la Gran Canaria, en Dramáticos posteriores a Lope de Vega, Tomo segundo, Atlas, Madrid, 1951, pp. 529-548.

234 No lo hemos identificado.

235 Juan Valverde de Amusco, Historia de la composición del cuerpo humano, Roma, 1556. Para Francisco Javier Puerto, Valverde (1525-1588) es el mejor anatomista español de su tiempo, quien «difundió la circulación menor por toda Europa y la presenta como fruto de su colaboración científica con Realdo Colombo ...; en la actualidad se desconoce si el de Serveto, Valvere y Colombo es un caso de descubrimiento múltiple o si los primeros conocieron el texto del segundo y no le citaron para evitarse problemas con la Inquisición, aunque los planteamientos y la descripción de los anatomistas son muy diferentes a los del autor aragonés» (PUERTO (1997), pp. 255 y 256). 
CAStro, A., Españoles al margen, Júcar, Madrid, 1973.

CASTro, A., Cervantes y los casticismos españoles, Alianza, Madrid, 1974.

CHARTIER, R., Libros, lecturas y lectores en la Edad Moderna, Alianza Editorial, Madrid, 1994.

Chevalier, M., Lectura y lectores en la España de los siglos XVI y XVII, Turner, Madrid, 1976.

DADSON, TREVOR J., Libros, Lectores y Lecturas. Estudios sobre bibliotecas particulares españolas del Siglo de Oro, Arcos/Libros, Madrid, 1998.

DEFOE, D., Memorias de guerra del capitán George Carleton. Los españoles vistos por un oficial inglés durante la Guerra de Sucesión, Universidad de Alicante, 2002.

DomíngueZ OrTIZ, A., Hechos y figuras del siglo XVIII español, Siglo XXI, Madrid, 1980.

Domínguez OrTIZ, A., Sociedad y Estado en el siglo XVIII español, Ariel, Barcelona, 1984.

Domínguez ORTIZ, A., «Estudio Preliminar» a Francisco Máximo de Moya Torres y Velasco, Manifiesto universal de los males envejecidos que España padece, Instituto de Cooperación Iberoamericana [etc.], Madrid, 1992.

Domínguez OrTiZ, A., España, tres milenios de historia, Marcial Pons, Madrid, 2000.

ENCISO ReCIO, L.M., «Prensa y Opinión pública», en La época de los primeros Borbones. La cultura española entre el Barroco y la Ilustración, t. XXIX, vol. II de la Historia de España fundada por Ramón Menéndez Pidal, Espasa-Calpe, Madrid, 1985, pp. 195-310.

ENCISO RECIO, L.M., Barroco e Ilustración en las bibliotecas privadas españolas del siglo XVIII. Discurso leído el día 17 de marzo de 2002 en la recepción pública de D. Luis Miguel Enciso Recio y contestación por el Excmo. Sr. D. Vicente Palacio Atard, Real Academia de la Historia, Madrid, 2002.

Epistolario español. Colección de cartas de españoles ilustres antiguos y modernos. Recogida y ordenada con notas y aclaraciones históricas, críticas y biográficas por D. Eugenio de Ochoa, tomo segundo, Atlas, Madrid, 1965.

Esteban PiÑeIro, M., y SALAVert Fabiani, V., «Las Matemáticas», en José María López Piñero (dir.), Historia de la ciencia y de la técnica en la Corona de Castilla. III. Siglos XVI y XVII, Junta de Castilla y León, Salamanca, 2002, pp. 231-257.

FEIJOO, B., Teatro crítico universal, 3 vols., Clásicos Castellanos, Madrid, 1968-1975.

FERnÁNDEZ HidAlgo, Ma del C. y GARCÍA RUIPÉREZ, M., Los ilustrados toledanos y la agricultura (1748-1820). Recopilación de textos agrarios, Diputación Provincial de Toledo, 1996.

GARCÍA BALLESTER, L., «La actividad intelectual médica de las minorías judía y mudéjar», y «La 'Çiençia y el ofiçio de la boticaría'», en Luis García Ballester (dir.), 
Historia de la ciencia y de la técnica en la Corona de Castilla. I. Edad Media, Junta de Castilla y León, Salamanca, 2002, pp. 789-825 y 865-911, respectivamente.

GARCÍA CÁRCEL, R., Las culturas del siglo de Oro, Historia 16, Madrid, 1989.

Gil Novales, A., «Política y Sociedad», en Centralismo, Ilustración y agonía del Antiguo Régimen (1715-1833), t. VII de la Historia de España dirigida por M. Tuñón de Lara, Labor, Barcelona, 1984, 175-320.

GILlisPIE, Ch. (ed.), Dictionary of Scientific Biography, t. IX, Charles Scribner's Sons, New York, 1974.

GonZÁlez Enciso, A., Felipe $V$ : La renovación de España. Sociedad y Economía en el reinado del primer borbón, Eunsa, Pamplona, 2003.

Gullón, R. (dir.), Diccionario de la Literatura Española e Hispanoamericana, 2 vols., Alianza Editorial, Madrid, 1993.

HIDALGO CÁMARA, E., «La química teórica y sus aplicaciones. Nuevas instituciones y nuevos saberes», en José Luis Peset (dir.), Historia de la ciencia y de la técnica en la Corona de Castilla. IV. Siglo XVIII, Junta de Castilla y León, Salamanca, 2002, pp. 417-464.

Hijano, A., El pequeño poder. El municipio en la Corona de Castilla: Siglos XV al XIX, Fundamentos, Madrid, 1992.

HiRSCH, A. (dir.), Biographisches Lexicon, Urban \& Schwarzenberg, Munich y Berlin, t. I, II y VI, 1962.

Iriarte, T. de, Poesías, Espasa-Calpe, Madrid, 1976.

ISLA, J.F. de, Fray Gerundio de Campazas, 4 vols., Espasa-Calpe, Madrid, 1969-1975.

LeÓn SANZ, V., «Estudio Preliminar» a Daniel Defoe, Memorias de guerra del capitán George Carleton, Universidad de Alicante, 2002.

LÓPEZ TERRADA, M ${ }^{\mathrm{a}}$.L., «Médicos, cirujanos, boticarios y albéitares», en José María López Piñero (dir.), Historia de la ciencia y de la técnica en la Corona de Castilla. III. Siglos XVI y XVII, Junta de Castilla y León, Salamanca, 2002, pp. 161-185.

LÓPEZ TERRADA, Ma.L. y SALAVERT FABIANI, V.L., «El barbero-cirujano», en La aventura de la Historia, no 5, Arlanza Ediciones, Madrid, 1999, pp. 80-84.

LóPEZ PIÑERO, J.M ${ }^{\mathrm{a}}$., «La Medicina», en José María López Piñero (dir.), Historia de la ciencia y de la técnica en la Corona de Castilla. III. Siglos XVI y XVII, Junta de Castilla y León, Salamanca, 2002, pp. 639-680.

MARTín VerdeJo, F., «A propósito de las Ordenanzas de Santa Olalla de 1623 y de un litigio entre ganaderos y hacendados del siglo XVIII», en Anales Toledanos, XXXVIII, Diputación Provincial, Toledo, 2001, pp. 83-112.

MARTínEZ PÉREZ, J.»La anatomía y los colegios de cirugía», en José Luis Peset Reig (dir.), Historia de la ciencia y de la técnica en la Corona de Castilla. IV. Siglo XVIII, Junta de Castilla y León, Salamanca, 2002, pp. 269-294. 
Moreno GonzÁlez, A., «La Física Moderna», en José Luis Peset Reig (dir.), Historia de la ciencia y de la técnica en la Corona de Castilla. IV. Siglo XVIII, Junta de Castilla y León, Salamanca, 2002, pp. 347-401.

Moya TORRES y Velasco, F. M. de, Manifiesto universal de los males envejecidos que España padece, Instituto de Cooperación Iberoamericana [etc.], Madrid, 1992.

MuÑoz CALVO, S., Historia de la farmacia en la España moderna y contemporánea, Síntesis, Madrid, 1994.

PALACIO ATARD, V., «Prólogo» a La época de los primeros Borbones. La nueva monarquía y su posición en Europa (1700-1759), tomo XXIX, vol. I de la Historia de España fundada por Ramón Menéndez Pidal, Espasa-Calpe, Madrid, 1985, pp. IX-LXXII.

Puerto Sarmiento, F.J., El mito de Panacea. Compendio de Historia de la Terapéutica y de la Farmacia, Doce Calles, Madrid, 1997.

PUERTO SARMieNTO, F.J., «Empirismo, arte y creencia, en la época de la razón: la terapéutica farmacológica ilustrada», en José Luis Peset (dir.), Historia de la ciencia y de la técnica en la Corona de Castilla. IV. Siglo XVIII, Junta de Castilla y León, Madrid, 2002, pp. 239-267.

REAl ACADEMIA ESPAÑola, Diccionario de la Lengua Española, vigésima primera edición, 2 vols., Espasa Calpe, Madrid, 1992.

Real ACAdemia Española, Diccionarios de Autoridades, ed. facs. (ed.orig. 1726), 3 vols., Gredos, Madrid, 1990.

STIFFONI, G., «Intelectuales, Sociedad y Estado», en La época de los primeros Borbones. La cultura española entre el Barroco y la Ilustración, t. XXIX, vol. II de la Historia de España fundada por Ramón Menéndez Pidal, Espasa-Calpe, Madrid, 1985, pp. 3-148.

Teruel Gregorio de TejadA, M., Vocabulario básico de la historia de la iglesia, Crítica, Barcelona, 1993.

\section{FUENTES DOCUMENTALES.}

\section{Archivo Diocesano de Toledo (A.D.T.):}

- Visitas Eclesiásticas, 1720-1734 A.

- Reparación de templos, Legajo 14, Expediente 14.

\section{Archivo Histórico Provincial de Toledo (A.H.P.T.):}

- Protocolo 5.783.

- $\quad$ “ 5.880 .

- $\quad$ “ 5.881 .

- $\quad$ “ 5.882 . 


$\begin{array}{rrr}- & \text { “ } & 5.883 . \\ \text { - } & \text { “ } & 5.884 . \\ \text { - } & \text { “ } & 5.885 . \\ \text { - } & \text { “ } & 5.886 . \\ \text { - } & \text { “ } & 5.887 . \\ \text { - } & \text { “ } & 13.788 . \\ \end{array}$

- Hacienda, signaturas 239 y 240.

- Universidad, signaturas I-356, I-353, I-448.

\section{Archivo Municipal de Domingo Pérez (A.M.D.P.):}

Libros de Acuerdos del Concejo.

\section{Archivo Parroquial de Domingo Pérez (A.P.D.P.):}

Libros de Bautismos.

Libros de Matrimonios.

Libros de Difuntos.

Libros de Fábrica de la Iglesia. 